\title{
Review \\ Polyphenoloxidase (PPO): Effect, Current Determination and Inhibition Treatments in Fresh-Cut Produce
}

\author{
Sergio Nogales-Delgado
}

check for updates

Citation: Nogales-Delgado, S. Polyphenoloxidase (PPO): Effect, Current Determination and Inhibition Treatments in Fresh-Cut Produce. Appl. Sci. 2021, 11, 7813. https:// doi.org/10.3390/app11177813

Academic Editor: Alexandros Ch. Stratakos

Received: 5 August 2021

Accepted: 24 August 2021

Published: 25 August 2021

Publisher's Note: MDPI stays neutral with regard to jurisdictional claims in published maps and institutional affiliations.

Copyright: (C) 2021 by the author. Licensee MDPI, Basel, Switzerland.

This article is an open access article distributed under the terms and conditions of the Creative Commons Attribution (CC BY) license (https:// creativecommons.org/licenses/by/ $4.0 /)$.
Department of Chemical Engineering and Physical-Chemistry, University of Extremadura, 06006 Badajoz, Spain; senogalesd@unex.es

Featured Application: Knowledge about PPO action, determination and inhibition processes applied to minimally processed fruit and vegetables.

Abstract: Fresh-cut produce are quite popular among consumers due to their eating ease, high quality and functional content. However, some of the processing steps taking place during minimal processing (such as cutting, peeling, draining, etc.) might speed up decay, e.g., microbial growth, dehydration or browning. When it comes to the latter, polyphenol oxidase (PPO) plays an important role, being the center of many works focused on the understanding of its reaction mechanism and the application of conservative techniques. The aim of this review study was to compare recent research about the effect of PPO on minimally processed fruits and vegetables, trying to understand the way it acts, the measurement of its activity and current treatments, such as modified atmosphere packaging, washing treatments or edible coatings, among others. In conclusion, the combination of conservation techniques (that is, hurdle technology) is vital to guarantee global quality in minimally processed fruits and vegetables, including synergistic effects which will allow the use of mild treatment conditions to decrease PPO activity. However, further research is required to clearly understand PPO inhibition in trendy techniques such as irradiation.

Keywords: minimally processed; fruits; vegetables; antioxidants; edible coatings; essential oils; modified atmosphere packaging

\section{Introduction}

\subsection{Fresh-Cut Fruits and Vegetables}

Minimally processed fruits and vegetables are highly demanded by consumers [1], growing their sales all over the world, as in the case of Europe [2]. This might be due to an increasing concern about health and lack of time to cook properly. Furthermore, minimally processed fruits and vegetables provide high functional and ready-to-eat food which are convenient products nowadays. Thus, there are a considerable amount of vegetables and fruits undergoing this technology, such as lettuce, cabbage, eggplant, apples, pears, peaches, plums, nectarines, etc. On account of the fact that fresh-cut produces come from whole vegetables and fruits, it is expected that these products have similar functional properties. Consequently, they contain high levels of fiber, minerals or antioxidants such as vitamins $\mathrm{C}$ and E, carotenoids, glucosinolates, polyphenols, etc. [3-6]. This fact has supposed an interesting research field for scientists, and its relevance has continuously increased. The trend in research about fresh-cut or minimally processed fruits and vegetables is shown in Figure 1. 

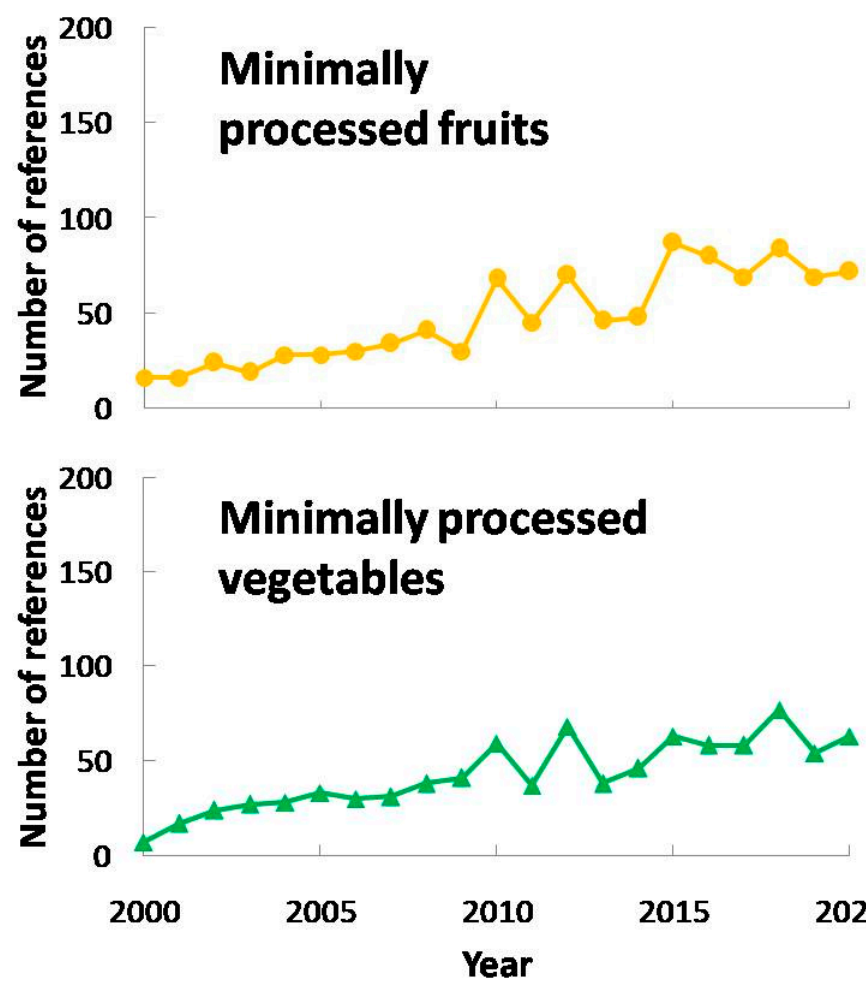

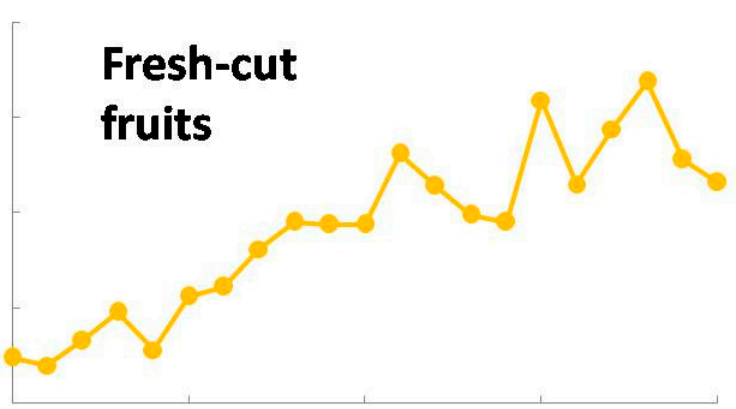

\section{Fresh-cut vegetables}

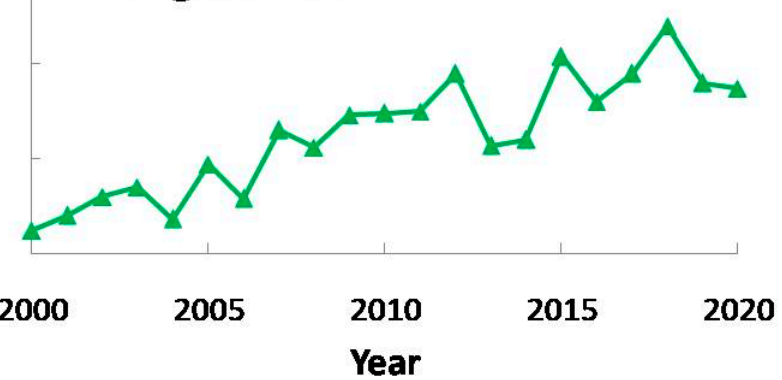

Figure 1. Research works related to minimally processed and fresh-cut fruits (yellow) and vegetables (green) [7].

As observed in this figure, there was a steady increase in research works about freshcut or minimally processed fruits and vegetables, mainly starting in 2000 with a few works and surpassing 150 studies per year in the past five years. In addition, there were more research works about fresh-cut or minimally processed fruits compared to vegetables. In conclusion, these figures point out the increasing interest in minimally processing so far.

\subsection{Main Deterioration Aspects in Minimal Processing}

However, even though the processing of fresh-cut fruits and vegetables is minimal, some aspects such as cutting and peeling promote a faster deterioration [8], involving physiological, biochemical and microbiological changes [9]. Hence, there are a lot of enzymes that take part in these changes, such as pectin methylesterase, polygalacturonase (both of them affecting texture), lipooxidase (generating off-flavor compounds) and polyphenol oxidase (EC 1.14.18.1 or PPO), among others. The latter plays an important role on visual quality decay causing browning, as it will be discussed in following sections. This deterioration might change consumers' choice as visual appearance is one of the highest rated aspects considered in order to purchase minimally processed fruits and vegetables. As a consequence, PPO has been widely studied (both in whole or minimally processed products) in order to characterize its content or to avoid its effect on quality of fruits or vegetables, (see Figure 2).

This way, PPO has been widely researched, and its interest has increased in the last two decades (Figure 2a). The same trend was observed for research about PPO and fresh-cut produce (Figure 2b), and if Figure 1 is taken into account, it can be noted that research about fresh-cut produce and its combination with PPO research are almost equivalent, pointing out the need of PPO characterization and the study of its consequences in fresh-cut fruits and vegetables in every research work in this field. 

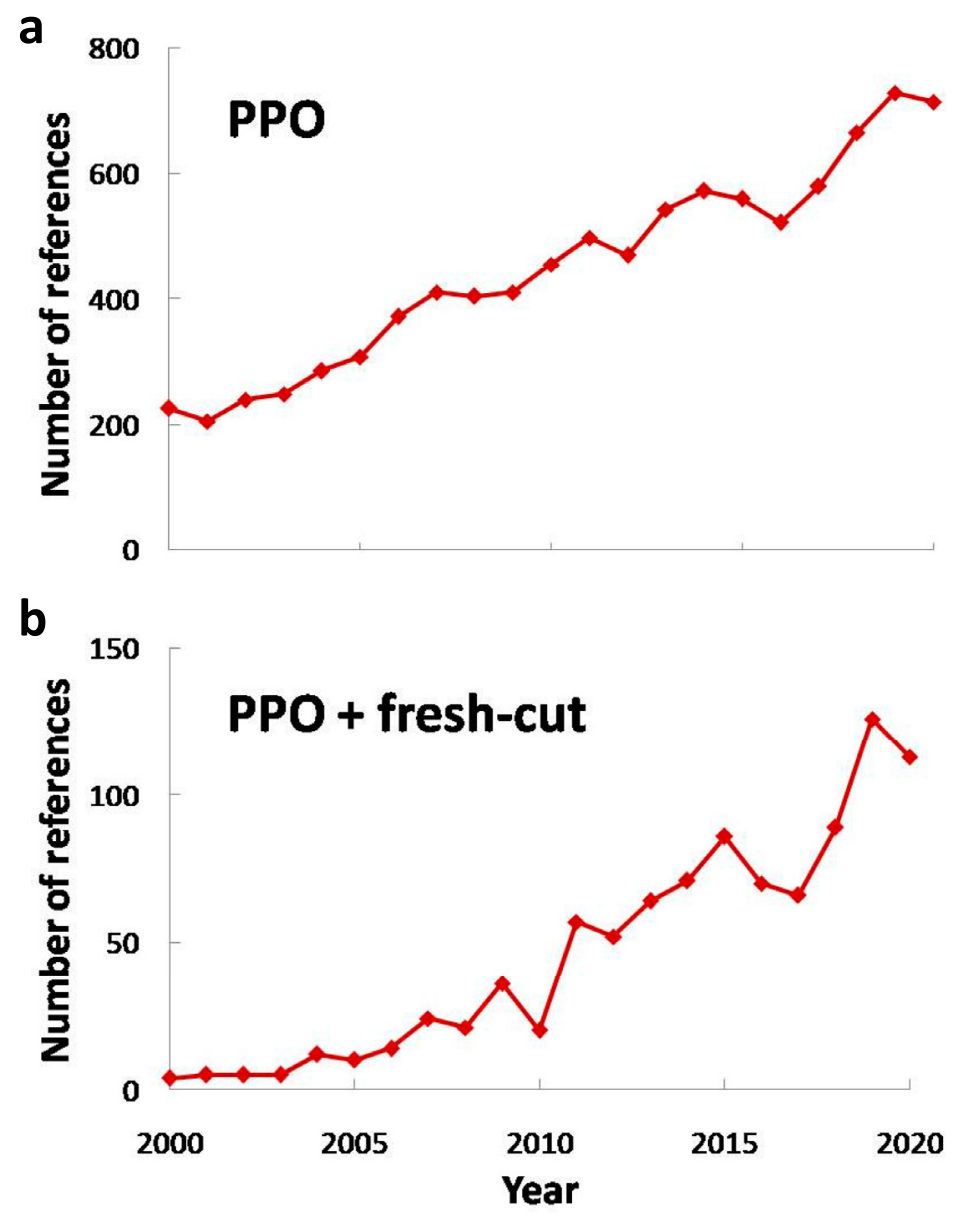

Figure 2. References related to: "PPO" and "PPO + fresh-cut" [7].

\section{PPO Effect on Fresh-Cut Produce and Its Mechanism}

As is known, browning of fresh fruit and vegetables reduces quality and is often the limiting factor regarding their shelf-life [8]. Enzymatic browning requires the presence of four different components: oxygen, an oxidizing enzyme, cooper and a suitable substrate such as phenols that are found mostly in vacuoles and apoplast/cell wall compartments [10]. Therefore, browning should be avoided by removing one of these components. The most important oxidizing enzyme is PPO, but there are others such as lipooxidase, which catalyzes peroxidation reactions, phenol peroxidase (EC 1.11.1.7 or POD), which contribute to enzymatic browning oxidizing hydrogen donors in the presence of hydrogen peroxide or phenylalanine ammonia lyase (PAL), that transforms the amino acid L-phenylalanine to trans-cinnamic acid [11,12]. Thus, phenol compounds synthesized by PAL might be oxidized by PPO. The latter catalyzes two reactions: a) hydroxylation of monophenols to o-diphenols (monophenolase or cresolase activity) and b) oxidation of o-diphenols to o-quinones (diphenolase or catecholase activity). The hydroxylation reaction is kinetically slower than the oxidation reaction. As a result, quinones are obtained as products. Due to their subsequent reactions (which are non-enzymatic), melanin accumulation takes place, and fruits and vegetables show brown, black or red pigments (depending on the polyphenolic substrate) related to browning [11,12] (see Figure 3). 


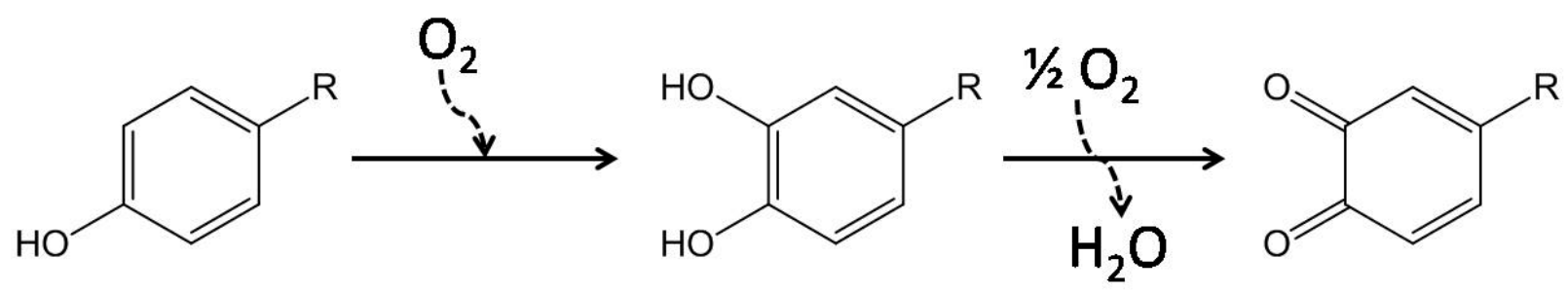

Figure 3. Main degradation steps of phenolic compounds.

In detail, PPO is an enzyme that contains two cooper atoms in its active center (see Figure 4). Depending on its enzymatic form transition (met, oxi or deoxi), PPO might have catecholase or mono-phenolase activity.
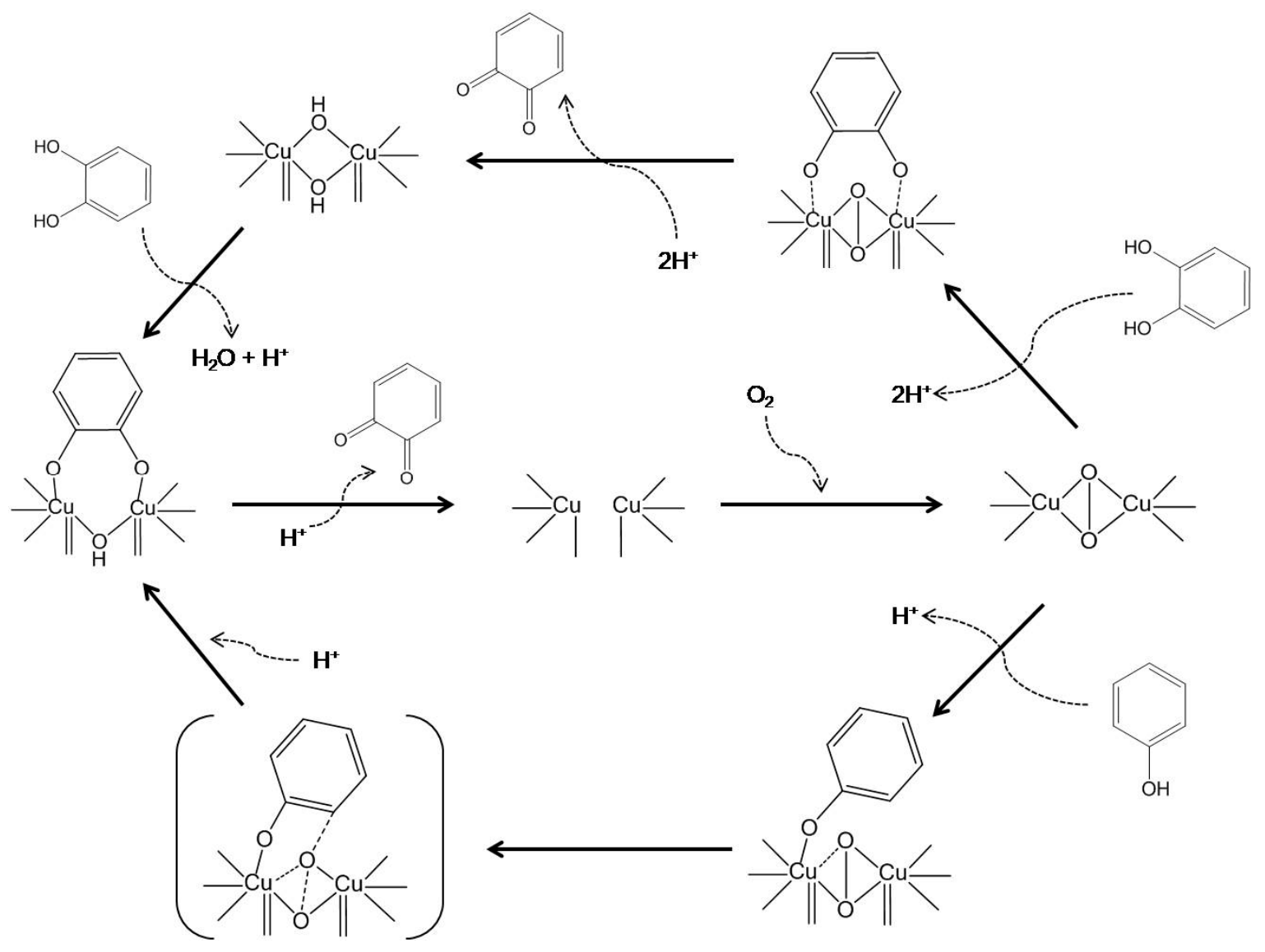

Figure 4. Detailed mechanism for polyphenol oxidase activity.

On the other hand, an additional discoloration effect was found for some fruit tissues, such as in the case of strawberries, probably due to deterioration of antocianines pigments [13]. During minimal processing, tissue integrity and the compartmentalization of cells are damaged, and all browning components are put in contact (that is, phenols and enzymes such as PPO or POD and oxygen). Thus, another way to retain browning is keeping compartmentalization in vegetable and fruit tissues. In addition, some authors have pointed out the possibility of synergistic effects between PPO and other enzymes such as POD [14].

Due to the fact that PPO mainly affects browning, it should be taken into consideration how color parameter evolution is during browning. Indeed, many authors have pointed out a close relationship between PPO activity and browning, concluding that PPO activity could be considered as a good browning indicator [15-19]. On the other hand, some authors have not found relevant correlation between these aspects, explaining that PPO 
activity differences could affect browning to a lesser extent, with browning evolution being negligible during storage for human eye $[20,21]$. In addition, other authors have not found any correlation between phenolic compound content and browning [21]. Thus, taking into account the CIELAB color space, an increase in browning is related to $\mathrm{L}^{*}$ decrease and $\mathrm{a}^{*}$ increase, and subsequently the hue angle $\left(\mathrm{h}^{*}\right)$ usually shows a diminution as well $[15,22,23]$. Consequently, this color decay might imply a reject by consumers when purchasing minimally processed products, reducing their shelf-life considerably.

\section{PPO Activity Assessment}

As explained earlier, there is a special need to assess PPO activity (among other enzymes) in order to assess its effect on browning. Even though there are different ways to assess PPO activity [24], the most common one used in fresh-cut produce was by spectrophotometry. In this case, whole produce and in-vitro assays follow similar procedures. In short, the steps are the ones gathered in Figure 5. Additionally, Tables 1 and 2 shows some details about PPO activity extraction and determination for vegetables and fruits, respectively.

\section{PPO assessment}

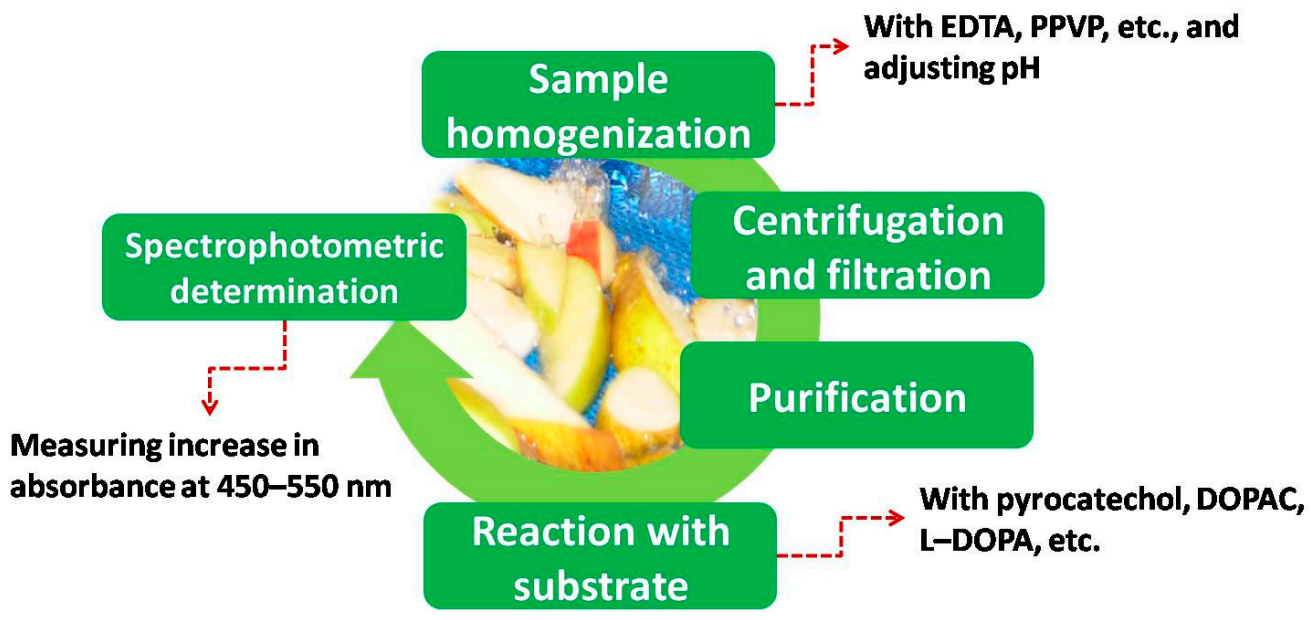

Figure 5. Steps for PPO assessment.

Table 1. Different conditions for PPO activity determination in some fresh-cut vegetables.

\begin{tabular}{|c|c|c|c|c|c|}
\hline \multirow[b]{2}{*}{ Produce } & \multirow[b]{2}{*}{ Reference } & \multirow[b]{2}{*}{ PPO Extraction } & \multicolumn{3}{|c|}{ Spectrophotometric Determination } \\
\hline & & & Substrate Solution & $\mathrm{pH}$ & $\begin{array}{l}\text { Wavelength } \\
(\mathrm{nm})\end{array}$ \\
\hline Artichoke & [14] & $\begin{array}{l}\text { PVP and acetate buffer }(\mathrm{pH} \\
5.6)\end{array}$ & Chlorogenic acid & 6.0 & 410 \\
\hline Artichoke & [25] & $\begin{array}{l}\text { Benzamidine, ascorbic acid, } \\
\text { PMSF, triton and phosphate } \\
\text { buffer ( } \mathrm{pH} 7.0)\end{array}$ & MBTH & 4.5 & 400 \\
\hline Carrot & [26] & $\begin{array}{l}\text { PVPP and phosphate buffer } \\
\text { (pH 6.5) }\end{array}$ & Catechol & 6.5 & 420 \\
\hline Carrot & [27] & Phosphate buffer ( $\mathrm{pH} 7.0$ ) & Catechol & 7.0 & 410 \\
\hline Eggplant & [28] & $\begin{array}{l}\text { Citrate phosphate buffer } \\
\text { (pH 7.0) }\end{array}$ & $\begin{array}{l}\text { DOPAC, MBTH, } \\
\text { methanol }\end{array}$ & 7.0 & 466 \\
\hline Eggplant & [29] & $\begin{array}{l}\text { PVP, PVPP, triton, ascorbic } \\
\text { acid and phosphate buffer } \\
\text { (pH 6.8) }\end{array}$ & 4-methylcatechol & 6.8 & 420 \\
\hline
\end{tabular}


Table 1. Cont.

\begin{tabular}{|c|c|c|c|c|c|}
\hline \multirow[b]{2}{*}{ Produce } & \multirow[b]{2}{*}{ Reference } & \multirow[b]{2}{*}{ PPO Extraction } & \multicolumn{3}{|c|}{ Spectrophotometric Determination } \\
\hline & & & Substrate Solution & $\mathrm{pH}$ & $\begin{array}{l}\text { Wavelength } \\
\text { (nm) }\end{array}$ \\
\hline Lettuce & [15] & $\begin{array}{l}\text { PVPP and phosphate buffer } \\
\text { (pH 6.5) }\end{array}$ & Catechol & 6.5 & 400 \\
\hline Lettuce & {$[30]$} & $\begin{array}{l}\text { PVPP and phosphate buffer } \\
\text { (pH 7.0) }\end{array}$ & Catechol & 7.0 & 420 \\
\hline Lettuce & [31] & $\begin{array}{l}\text { Acetone, MBTH and citrate } \\
\text { phosphate buffer (pH 7.5) }\end{array}$ & DOPAC & 7.0 & 505 \\
\hline Lettuce & [32] & Phosphate buffer (pH 7.0) & MBTH & 7.0 & 467 \\
\hline Lotus root & [33] & $\begin{array}{l}\text { PVPP and phosphate buffer } \\
\text { (pH 7.0) }\end{array}$ & Catechol & 7.0 & 410 \\
\hline Mushroom & {$[34]$} & PVPP and $\mathrm{NaCl}(\mathrm{pH} 6.5)$ & Catechol & 7.0 & 400 \\
\hline Mushroom & {$[35]$} & $\begin{array}{l}\text { PVPP, triton and phosphate } \\
\text { buffer ( } \mathrm{pH} 6.8)\end{array}$ & Catechol & 6.8 & 420 \\
\hline Potato & [36] & $\begin{array}{l}\text { PVPP and phosphate buffer } \\
\text { (pH 6.0) }\end{array}$ & 4-methylcatechol & 6.0 & 410 \\
\hline Potato & [37] & Phosphate buffer (pH 6.5) & Catechol & 6.5 & 410 \\
\hline Potato & [38] & PBS (pH 6.8) & Catechol & 5.5 & 405 \\
\hline Potato & [39] & $\begin{array}{l}\text { PVP, triton and phosphate } \\
\text { buffer ( } \mathrm{pH} 6.8)\end{array}$ & Catechol & 7.0 & 475 \\
\hline Red beet & [40] & $\begin{array}{c}\mathrm{NaCl}, \mathrm{PVP} \text { and } \\
\text { phosphate-citrate buffer }(\mathrm{pH} \\
6.5)\end{array}$ & Pyrocatechol & 6.5 & 420 \\
\hline Red beet & [41] & $\begin{array}{l}\mathrm{NaCl} \text { and phosphate buffer } \\
(\mathrm{pH} 6.0)\end{array}$ & Pyrocatechol & 7.0 & 420 \\
\hline weet peppers & {$[42]$} & $\begin{array}{c}\text { Acetone and citrate phosphate } \\
\text { buffer ( } \mathrm{pH} 7.5)\end{array}$ & DOPAC & 7.0 & 505 \\
\hline
\end{tabular}

DOPAC = 3,4-dihydroxyphenyl acetic acid; EDTA = Ethylenediaminetetraacetic acid; $\mathrm{MBTH}$ = 3-methyl-2-benzothiazolinone hydrazine; PBS

$=$ Phosphate buffered saline; PMSF $=$ Phenylmethylsulphonyl fluoride; PVP = Polyvinylpyrrolidone; PVPP = Polyvinyl polypyrrolidone.

Table 2. Different conditions for PPO activity determination in some fresh-cut fruits.

\begin{tabular}{|c|c|c|c|c|c|}
\hline \multirow[b]{2}{*}{ Produce } & \multirow[b]{2}{*}{ Reference } & \multirow[b]{2}{*}{ PPO Extraction } & \multicolumn{3}{|c|}{ Spectrophotometric Determination } \\
\hline & & & $\begin{array}{l}\text { Substrate } \\
\text { Solution }\end{array}$ & $\mathrm{pH}$ & $\begin{array}{l}\text { Wavelength } \\
(\mathrm{nm})\end{array}$ \\
\hline Apple & [19] & PVPP and phosphate buffer (pH 7.0) & Cathecol & 5.8 & 420 \\
\hline Apple & {$[43]$} & PVPP and phosphate buffer (pH 5.0) & 4-methylcatechol & 5.0 & 494 \\
\hline Apple & {$[44]$} & Triton and phosphate buffer (pH 7.2) & Chlorogenic acid & 5.2 & 420 \\
\hline Apple & {$[45]$} & $\begin{array}{l}\text { PVPP, triton and Phosphate buffer } \\
(\mathrm{pH} 7.0)\end{array}$ & Citrate-phosphate & 5.0 & 420 \\
\hline Apple & {$[46]$} & Potassium phosphate buffer (pH 7.0) & Sodium acetate & 5.5 & 405 \\
\hline Banana & [18] & $\begin{array}{l}\text { PVPP, triton and phosphate buffer } \\
\text { (pH 6.5) }\end{array}$ & Catechol & 6.5 & 420 \\
\hline Carambola & {$[47]$} & $\begin{array}{l}\text { PVPP, } \mathrm{KCl} \text { and phosphate buffer ( } \mathrm{pH} \\
6.8)\end{array}$ & Catechol & 7.2 & 410 \\
\hline Carambola & [48] & $\begin{array}{l}\text { PVPP, } \mathrm{KCl} \text { and phosphate buffer ( } \mathrm{pH} \\
6.8)\end{array}$ & Catechol & 7.2 & 410 \\
\hline
\end{tabular}


Table 2. Cont.

\begin{tabular}{|c|c|c|c|c|c|}
\hline \multirow[b]{2}{*}{ Produce } & \multirow[b]{2}{*}{ Reference } & \multirow[b]{2}{*}{ PPO Extraction } & \multicolumn{3}{|c|}{ Spectrophotometric Determination } \\
\hline & & & $\begin{array}{l}\text { Substrate } \\
\text { Solution }\end{array}$ & $\mathrm{pH}$ & $\begin{array}{l}\text { Wavelength } \\
(\mathrm{nm})\end{array}$ \\
\hline Coconut water & [49] & Phosphate buffer (pH 5.5) & Pyrocatechol & 5.5 & 470 \\
\hline Jicama & {$[50]$} & PVPP and phosphate buffer (pH 7.0) & Catechol & 7.0 & 420 \\
\hline Papaya & [51] & Sodium phosphate buffer ( $\mathrm{pH} 6.5$ ) & Catechol & 6.5 & 420 \\
\hline Peach & {$[52]$} & $\begin{array}{l}\text { PMSF, PVPP, triton and phosphate } \\
\text { buffer ( } \mathrm{pH} 6.8)\end{array}$ & L-Dopa & 6.8 & 475 \\
\hline Peach & [10] & $\begin{array}{l}\text { EDTA, } \mathrm{MgCl}_{2}, \text { PMSF, PVPP, triton } \\
\text { and phosphate buffer ( } \mathrm{pH} 7.0)\end{array}$ & Resorcinol & 7.0 & 500 \\
\hline Peach & [53] & $\begin{array}{l}\text { EDTA, PVPP and phosphate buffer } \\
\qquad(\mathrm{pH} 7.0)\end{array}$ & - & 7.0 & 420 \\
\hline Pear & [54] & $\begin{array}{c}\text { Dihydrogen phosphate buffer ( } \mathrm{pH} \\
6.8)\end{array}$ & Catechol & 6.8 & 398 \\
\hline Pear & [55] & Triton and phosphate buffer ( $\mathrm{pH} 7.2$ ) & Chlorogenic acid & 4.2 & 420 \\
\hline Strawberry & [13] & $\begin{array}{l}\text { PVPP, triton and phosphate buffer } \\
\qquad(\mathrm{pH} 6.5)\end{array}$ & Catechol & 6.5 & 420 \\
\hline
\end{tabular}

EDTA = Ethylenediaminetetraacetic acid; PMSF = Phenylmethylsulphonyl fluoride; PVPP = Polyvinyl polypyrrolidone.4. Current studies focused on PPO activity.

Thus, homogenization is required, mixing up the sample with some components such as EDTA, PMSF or PVPP and adjusting pH (generally between 6 and 8) with buffer [24]. After centrifugation and filtration, the spectrophotometric reaction takes place adding the extract to a reactive environment with suitable substrates and adjusting $\mathrm{pH}$. Molecular structures of some of the most used substrates are shown in Figure 6.<smiles>Cc1ccc(O)c(O)c1</smiles>

a<smiles>Oc1ccccc1O</smiles>

b<smiles>Oc1cccc(O)c1</smiles>

C<smiles>O=C(O)Cc1ccc(O)c(O)c1</smiles><smiles>Cn1/c(=N/N)sc2ccccc21</smiles><smiles>O=C(C#Cc1ccc(O)c(O)c1)O[C@@H]1C[C@@](O)(C(=O)O)C[C@H](O)[C@H]1O</smiles><smiles>N[C@@H](Cc1ccc(O)c(O)c1)C(=O)O</smiles>

Figure 6. Molecular structures of some common subtracts used in PPO activity determination for fresh-cut produce: (a) 4-methylcatechol; (b) pyrocatechol (catechol); (c) resorcinol; (d) DOPAC; (e) MBTH; (f) chlorogenic acid; (g) L-DOPA. 
Finally, the increase in absorbance is measured at the beginning of the reaction (usually for $3 \mathrm{~min}$ ), using wavelengths from 450 to 550. Figures 5 and 6 show some of the most common extracts used in spectrophotometric determination of PPO activity applied to different fresh-cut vegetables and fruits, respectively.

\section{Current Studies Focused on PPO Activity}

\subsection{PPO Distribution}

PPO activity distribution is important, especially taking into account that in minimal processing some parts of the produce are valuable (such as pulp) at the expense of others (such as peel, stones, cores, etc.) which are usually removed. This way, there might be differences in PPO content depending on the state of the fruit or vegetable (whole or fresh-cut), affecting to the propensity to browning. As a consequence, this aspect was studied in some vegetables. In general, it was found that PPO activity was higher (two to four-fold) in photosynthetic tissues than in vascular ones. These findings were probably due to the location of PPO and POD in the thylakoid membrane of the chloroplasts [17,56]. Concerning fruits, PPO activity distribution is variable depending on the tissue. For example, rambutan PPO activity was higher in spinterns than in the peel, probably due to the higher oxygen transmission into spinterns [57].

\subsection{Fruit and Vegetables Characterizationand Processing}

In order to understand PPO behavior in fresh-cut produce, some characterization in whole fruits and vegetables is needed. As is known, PPO and phenol content in fruits are important in order to explain browning. Many authors have claimed that these contents might vary depending on the cultivar and fruit development or ripening [58,59]. That is the reason why some studies have focused on pre-harvest behavior or ripening evolution (when the sample is collected) of some fruits and vegetables. For instance, the characterization of membrane-bound polyphenol oxidase from Granny Smith apples was carried out, which provided interesting information to understand the behavior of PPO during processing in order to improve the quality of minimally processed apples [60]. On the other hand, PPO content was measured during ripening for medlar, finding rapid enzymatic browning as the fruit softened and observing an increase in PPO activity and a decrease in polyphenol content during ripening [58]. Another study on rambutan was carried out so as to characterize it when it comes to PPO activity, showing high polyphenol contents and PPO activity (especially in spinterns, compared to peel), which could explain (along with dehydration) browning during storage [57]. Furthermore, a study about the suitability of five potato cultivars for fresh-cut processing was published, paying special attention to browning and PPO activity. In this case, "Marabel" cultivar showed the lowest phenol content and PPO activity and the longest shelf-life, due to the maintenance of global quality (including the subsequent decrease in browning evolution) [36]. Lettuces cultivated in different salinity conditions were evaluated in order to assess its suitability for fresh-cut processing, paying special attention to PPO activity and browning. Thus, low salinity conditions $\left(2.8 \mathrm{dS} \mathrm{m}^{-1}\right)$ were not suitable due to the high PPO activity, being reduced when salinity was increased [31]. Another similar study showed that the use of high salinity solutions $\left(4.8 \mathrm{mS} \mathrm{cm}^{-1}\right)$ could slightly reduce PPO activity, especially at the end of storage [61]. In addition, six genotypes of artichoke were studied for minimal processing, focusing on PPO activity and browning, with "Romolo" cultivar being the most suitable one [14]. Minimally processed sweet peepers were studied according to their PPO activity evolution during storage. Thus, yellow peppers were less suitable for minimal processing, showing the green ones lower PPO activities [42]. Finally, some authors have studied how irrigation affects fresh-cut lettuce, finding that high irrigation regimes conveyed high PPO activity during storage [32]. But not only pre-harvest conditions are vital to understand PPO activity. In that sense, processing (including cutting, heat treatments, etc.) can affect phenol content, due to PPO activity, among other factors [62]. As pointed out in the literature, processing, even when it comes to cutting styles, can accelerate PPO activity, as 
it happened in the case of fresh-cut potatoes, where shredding had a negative effect [63] or lettuce, where cutting induced an increase in PPO activity in minimally processed lettuce [64].

\subsection{PPO Evolution in Fresh-Cut Produce}

In addition tothe mechanism and studies related to PPO, much research about PPO evolution in fresh-cut fruits and vegetables have been carried out to check PPO relevance, especially during storage. As commented elsewhere, $\mathrm{PPO}$ activity tends to increase during storage, achieving a summit. Afterwards, PPO activity might decrease. In fact, there are studies comparing both minimally processed and intact lettuce, escarole and rocket salad and their enzyme content evolution (including PPO). As expected, different behavior was found depending on the produce and their ascorbic acid content. Namely, escarole showed intense browning. Thus, cutting increased PAL activity, but did not affect PPO nor POD for lettuce and escarole [21]. On the other hand, another study pointed out the vital importance of using sharp blades in order to avoid an increase of PPO activity for fresh-cut eggplant, trying to reduce the impact on tissue destruction [29]. Some authors have found an increasing PPO activity in fresh-cut produce during storage, especially up to the eighth or ninth day, showing occasionally a decrease from then on, possibly due to the decrease in polyphenol content $[10,15,22,65]$.

\subsection{Influence on PPO Activity}

According to many researchers, as included in Figure 7, the main factors affecting PPO activity are temperature, $\mathrm{pH}$, cell integrity, pre-harvest conditions and microbial activity, which will be explained in the following sections.

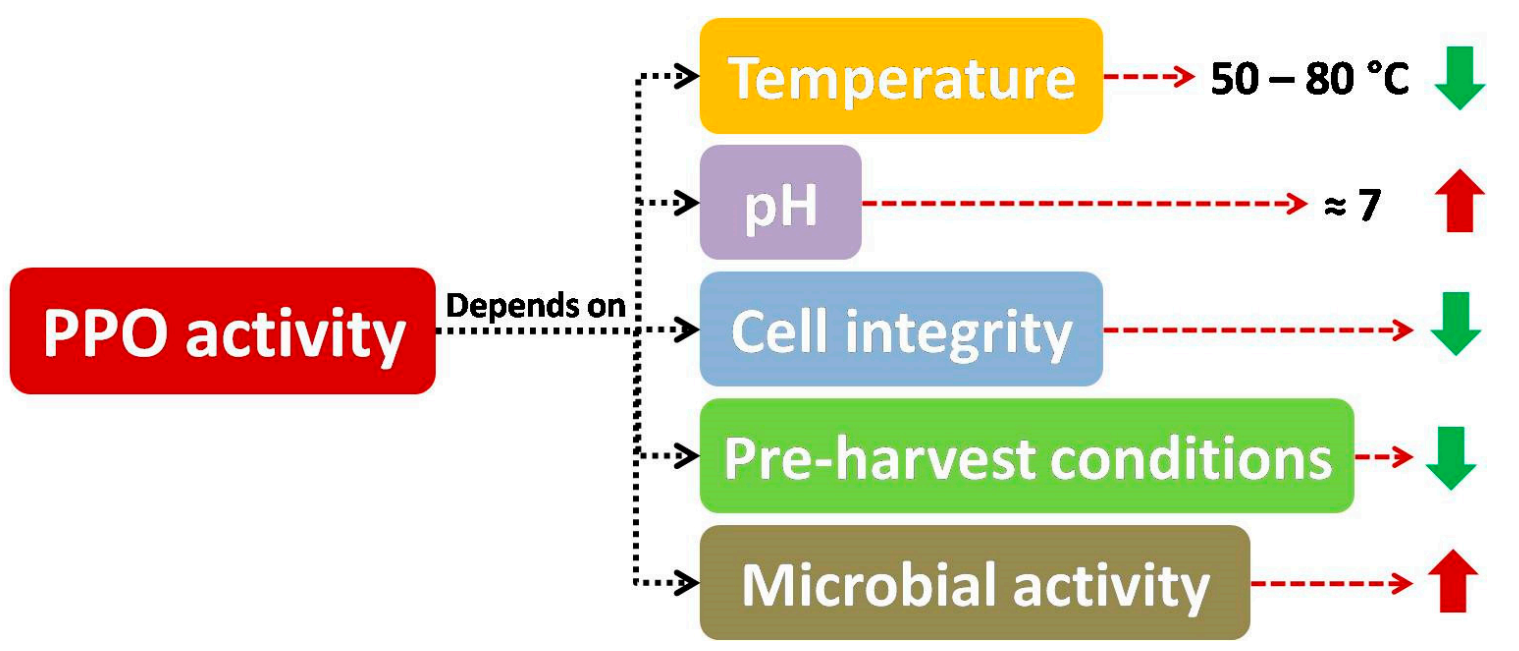

Figure 7. Influence of main factors on PPO activity, indicating its positive (green down arrow) or negative effect (red up arrow) and some specific conditions.

\subsubsection{Temperature}

As it will be seen later on, one of the techniques used in order to reduce PPO activity (as in other enzymes) is heating, pointing out the importance of temperature on PPO activity, which has been considered in the literature. In this case, two factors should be taken into account: inactivation temperature of the enzyme and storage temperature of postharvest or fresh-cut fruits and vegetables. Thus, temperatures from 50 to $80^{\circ} \mathrm{C}$ seem to be effective when inhibiting PPO activity during washing for many products such as freshcut peach, whose browning and firmness was maintained during storage after applying the abovementioned temperatures [52]. On the other hand, it is well known the low effect of temperature on browning and other undesirable effects during storage. Thus, some studies have been carried out to assess how storage temperature affected PPO activity on fresh-cut 
carambola slices, not showing significant differences between storage temperatures from 2.5 to $10^{\circ} \mathrm{C}[48]$.

\subsection{2. $\mathrm{pH}$}

Regarding $\mathrm{pH}$, two opposite effects can be found in PPO activity, one related to PPO by itself and another one affecting the effectiveness of different washing treatmentsused in minimal processing in order to maintain browning and inhibit PPO activity, among other purposes (as it will be commented in following sections). In general, PPO shows a higher activity in cut surfaces of minimally processed produce at a neutral $\mathrm{pH}$ (approximately 7 ) and in the range $30-50{ }^{\circ} \mathrm{C}$, being completely inactivated at $80^{\circ} \mathrm{C}$ in most cases (considering minimally processed apple, pear or medlar) $[8,58,66,67]$. However, depending on the produce, $\mathrm{pH}$ optimal range might vary, as it happened to fresh-cut pears, pointing out the importance of pre-harvest factors in many aspects of PPO activity, not only paying attention to its initial content [68]. Concerning the effectiveness of some treatments depending on $\mathrm{pH}$, this fact might influence on the use of coatings or antioxidants. Thus, some anti-browning additives depend on the $\mathrm{pH}$ of the washing treatment, and some studies have found that the optimum $\mathrm{pH}$ range was found at around 7, as in the case of cysteine for minimally processed artichoke or calcium lactate for fresh-cut pears. In both cases, it was pointed out the selection of the optimum $\mathrm{pH}$ range in order to improve the effectiveness of the washing treatment, which is vital at industrial scale $[25,69]$.

\subsubsection{Cell Integrity}

As explained in following subsections, cell integrity plays a vital role in PPO activity, as cell lysis can accelerate browning due to the fact that PPO is put in contact with phenolic compounds and oxygen. In that sense, minimally processing tends to destroy tissues and cells, increasing or promoting browning. That is the reason why some treatments such as those related to calcium are used in order to improve or keep cell and membrane integrity, if possible [11].

\subsubsection{Pre-Harvest Conditions}

As explained in previous sections concerning fruit and vegetable characterization, these conditions have been widely studied, as they present a high influence on some characteristics of fruits and vegetables both whole and minimally processed, including firmness, flavor, functional compounds, water loss, etc.

Regarding cultivar selection, for instance, the composition or characteristics of different cultivars might considerably vary in fruits or vegetables (both whole or minimally processed), especially concerning PPO and polyphenol content, turgence or water loss. Specifically, PPO activity seems to play an important role in potato, whose susceptibility to blackspot can be predicted depending on the geometric parameter of the microstructure of tuber parenchyma, determined at harvest [70]. Indeed, depending on the cultivar, different potato samples presented long term storage stabilities such as "Purple" and "Satsumo Imo" varieties [71]. Another study pointed out the influence of cultivar on water loss in fresh-cut fruits during storage, pointing out that other factors such as temperature could equally play an important role [72].

On the other hand, other pre-harvest conditions such as climate, including irrigation or rain conditions, can influence on the characteristics of fruits or vegetables during storage. Thus, in the case of two potato cultivars with different drought sensitivity, different respiration rates and glucose or fructose content were found during storage [73].

Finally, maturity of the collected sample is another key factor affecting quality of fresh-cut produce, as in the case of minimally processed pomegranate arils, where maturity (as well as cultivar selection) had an important influence on flavor after processing and during storage, with considerable changes volatile profile during fruit maturation [74]. 


\subsubsection{Microbial Growth and Decay}

Apart from the activity of endogenous quality degrading enzymes, spoilage microorganism reaction considerably shortens the shelf life of fruit and vegetable products, both whole and fresh-cut produce [75,76]. Furthermore, microbial growth can be a matter of concern, with many studies considering microbial safety in minimally processed samples [77], as in the case of cantaloupe pieces [78].

As included in some studies, the effect of enzymes and microbial growth on shelf life of minimally processed fruits and vegetables could be synergistic, as microorganisms can worsen cell integrity of tissues, provoking cell lysis, which is highly related to the increase in enzyme activity, as enzymes and substrates are easily put in contact, accelerating decay in fruits and vegetables (both whole and fresh-cut samples) [79]. On the other hand, microbial growth and enzymatic reactions can present a common starting point (i.e., cell lysis) to put some components included in cell content (such as sugar or phenols for microbial counts or PPO activity, respectively), and consequently these two adverse effects can act in parallel. As a consequence, if some techniques promote cell reinforcement are used (such as the application of calcium treatments), a combined decrease in microbial and PPO activity can be observed, as outlined below.

This way, the effect of microbiological activity on some visual defects has been investigated in several papers that considered the relationship between psychrotrophic counts and visual decay [78]. As some authors have pointed out, the use of protective treatments seemed to be related to a direct decrease in browning, enzyme activity (such as PPO) and microbial growth $[77,80]$, as in the case of edible coatings applied to fresh-cut fruits and vegetables [81]. Specifically, the reduction of microbial population may result in PPO activity inhibition, on account of the fact that pectinolytic micro-organisms could break down cell walls resulting in stress-related exposure of enzymes and substrates, which also could lead to enzymatic browning. Hence, some barriers such as modified atmosphere packaging or washing treatments might contribute (besides their direct effects on browning inhibition) to reduce microbial population and therefore reduce PPO activity, improving visual quality [82,83], as explained in many papers included in this review, although the decrease in microbial growth is not thoroughly covered in this work.

\section{Current Treatments to Avoid or Reduce PPO Activity in Fresh-Cut Produce}

In order to avoid the negative effects of PPO activity, or at least to reduce them, many treatments have been used in fresh-cut or minimally processed produces. Some of them can be exclusively used to reduce PPO activity, whereas others can show other beneficial effects on fresh-cut produce, such asantimicrobial effect, inhibition on other enzymes, etc. On the other hand, some of these treatments can be combined, such asthe use of washing with antioxidants or essential oils, the use of edible coatings containing antioxidants or the combined use of washing and modified atmosphere packaging, presenting additive or synergistic effects in many cases. In any case, some of the treatments that have drawn attention to researchers are included in Figure 8. It should be pointed out that the search for mild treatments (by combining techniques or using the hurdle technology) seems to be one interesting and resourceful option for researchers, in order to avoid other undesirable effects on fresh-cut fruits and vegetables [84]. 

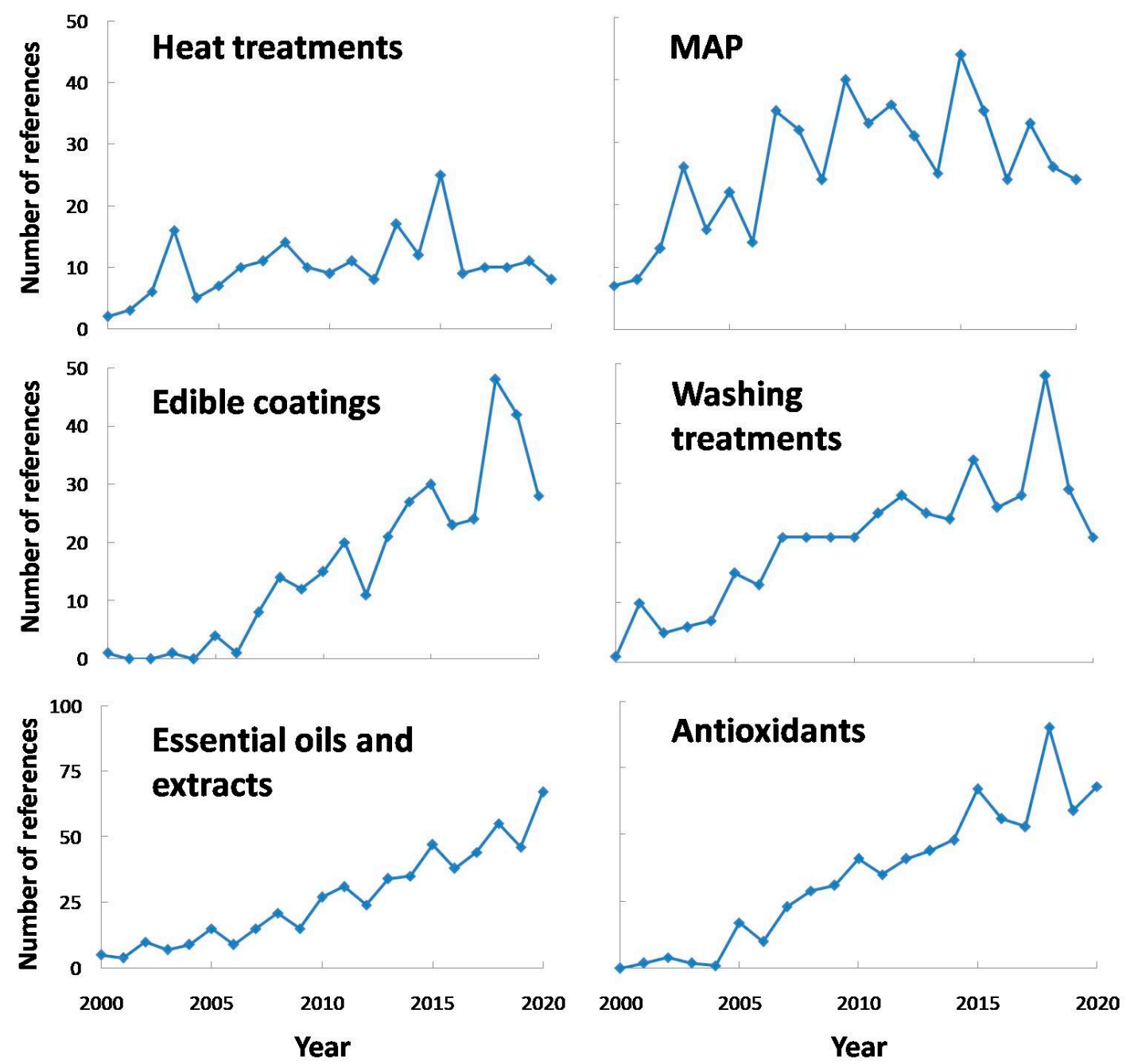

Figure 8. Main trends for treatments in order to keep quality of fresh-cut produce. Search words: Heat treatments, modified atmosphere packaging (MAP), edible coatings, washing treatments, essential oils and extracts and antioxidants. Source: Scopus [7].

As observed in this figure, the use of essential oils, extracts and antioxidants in general seemed to be the most used treatments in order to keep quality in fresh-cut produce, with an increasing and steady trend in the past 20 years. Even though less investigated, other techniques such as heat treatments, MAP or edible coatings should be taken into account, especially the latter, which showed a considerable increase in publications in the past decade. Thus, the specific effects of these treatments (among others) on PPO activity will be discussed in the following subsections.

\subsection{Heat Treatments}

Thermal methods have been extensively used for food preservation. In order to avoid loss of some food properties such as vitamins, texture, fresh appearance, etc., it is applied in short times. Thus, temperature affects microbial and enzymatic activity whereas time affects quality loss [8,85]. Regarding PPO, its activity is extremely affected. As commented earlier, temperatures from 50 to $80^{\circ} \mathrm{C}$ seem to be effective for inhibiting PPO activity during washing of many products such as lettuce, celery or peaches, among others, retaining quality parameters such as firmness in the case of minimally processed peaches [52]. Another aspect to take into account is the time of application. Thus, blanching treatments have been carried out in order to inactivate undesirable enzymes in fruit and vegetable tissues. However, softening might be found in blanching. Some authors have studied the effect of washing treatment temperature on PPO activity for apples, pointing 
out that high temperatures (from 55 to $65^{\circ} \mathrm{C}$ ) for short periods (30 s) were more effective, combined with a treatment of $0.6 \%$ calcium chloride [86]. The use of blanching (by steam or microwaves) and osmotic dehydration was also carried out in minimally processed strawberries (where the effect of PPO does not imply browning, but loss of red color due to anthocyanin deterioration), showing no color changes possibly due to enzyme deactivation [13]. Similar findings were found for mild heat pre-treatments on pears, with an optimal temperature-time range of $35-45^{\circ} \mathrm{C}$ for $40-150 \mathrm{~min}$ [66]. For fresh-cut iceberg lettuce, different calcium lactate solutions were found to be more effective in inhibiting PPO at $50{ }^{\circ} \mathrm{C}$ for $1 \mathrm{~min}$, pointing out the suitability of the combined use of different treatments in order to keep global quality in minimally processed fruits and vegetables [15]. In parallel, in the case of fresh-cut apple slices, the use of hot water (at 60 or $70^{\circ} \mathrm{C}$, depending on the variety) combined with ascorbic acid or citric acid solution ( $1 \%$ in both cases) showed the best results to control browning development [87]. However, some side effects can be observed during heat treatments, such as vitamin deterioration, which points out the need of further studies to optimize temperatures and time treatments in order to avoid these inconvenient effects. For instance, blanching at $100{ }^{\circ} \mathrm{C}$ was effective at reducing PPO activity in lettuce, but other antioxidants such as carotenes and ascorbic acid were reduced due to the heat treatment [56]. Indeed, further studies were carried out in order to optimize blanching time, concluding that the longer the treatment was, the less PPO activity was found (especially for vascular tissues), needing an intermediate solution in order to avoid extreme carotenoids or ascorbic acid deterioration in fresh-cut lettuce [17]. For peaches, a $50{ }^{\circ} \mathrm{C}$ heat pre-treatment for $10 \mathrm{~min}$ was effective in avoiding browning when the fruit was minimally processed. However, no PPO activity differences were found between treated and control samples [52]. Regarding the effect of heat treatments on quality parameters of fresh-cut sugarcane, a treatment at $45^{\circ} \mathrm{C}$ for $3 \mathrm{~h}$ was tested, showing positive results in PPO activity (reducing its activity compared to control samples) [88].

\subsection{Modified Atmosphere Packaging and Controlled Atmosphere \\ 5.2.1. Traditional MAP or CA}

Traditional modified atmosphere packaging can extend fresh-cut produce's shelf-life because of its low $\mathrm{O}_{2}$ and/or high $\mathrm{CO}_{2}$ composition. Thus, by reducing oxygen (avoiding anaerobic respiration) cut browning effects might be reduced, among other effects in fruit and vegetables $[80,89]$. Following this conservative technique, many authors have studied the effect of different MAP treatments on fruits and vegetables. For instance, the effect of different materials used for MAP was assessed for fresh-cut carambola, finding the polyolefin bags as the most suitable film because of PPO activity reduction (probably due to firmness conservation, which avoided the contact of enzymes and substrates) [47]. Different MAP treatments (combined with antioxidant and calcium washing treatments) were carried out for pitted jackfruit fruits, in order to assess browning index (which was considerably reduced), extending the shelf life of the samples for 35 days at $6{ }^{\circ} \mathrm{C}$ [90]. Even controlled atmospheres $\left(1 \mathrm{kPa} \mathrm{CO}_{2}+1 \mathrm{kPa} \mathrm{O}\right.$ and $\left.3 \mathrm{kPa} \mathrm{CO}+3 \mathrm{kPaO}_{2}\right)$ has been used as a pre-treatment so as to avoid browning in fresh-cut apple, and changes in PPO activity depending on CA were negligible [19]. In addition, the use of high $\mathrm{CO}_{2}$ concentrations in fresh-cut pear kept quality parameters such as firmness or color, inhibiting browning [91,92]. However, the effect of these techniques might be short. Thus, when the sample is put in contact with oxygen (for example, by opening the package) browning might restart [33]. Recently, new materials have been tested to be introduced in MAP, such as the use of $\mathrm{ZnO}$ nanoparticles into poly-lactic matrix, showing interesting results and keeping the properties of fresh-cut apples for 14 days at $4{ }^{\circ} \mathrm{C}$, decreasing PPO activity. In addition, other studies have focused on anoxia treatments, where the sample is exposed to pure $\mathrm{N}_{2}$. In that sense, the browning inhibition of this technique was proved in fresh-cut Chinese water chestnut, including changes in PPO activity [93]. In addition, the use of sustainable materials seems to play an important role in active packaging, as in the case of onion solid wastes, which were used to produce active packages which reduced browning in fresh-cut 
produce [94]. However, some studies did not find MAP effective enough to prevent cut browning. Therefore, some complementary treatments are needed (for example cysteine washing treatments) [95]. Indeed, many authors have used MAP combined with other washing treatments such as citric and ascorbic acid, calcium chloride, calcium ascorbate, chitosan, etc. [69,96-99]. Finally, as explained previously, pre-harvest or pre-processing treatments can influence on the performance of fresh-cut produce, as in the case of the use of modified atmospheres in whole fruits before minimal processing. Thus, an interesting study showed the effect of 1-MCP during postharvest on fresh-cut blanquilla pear. Its antioxidant potential was found responsible for the better tissue integrity, hindering PPO coming in contact with phenols once minimal processing was carried out [100].

\subsubsection{High $\mathrm{O}_{2}$ Partial Pressure}

On the other hand, the use of high $\mathrm{O}_{2}$ partial pressure could be an alternative for traditional MAP. This way, high oxygen levels may cause substrate inhibition of PPO or form colorless quinines that could lead to PPO feedback inhibition [97]. Thus, studies of high-oxygen atmosphere on minimally processed potatoes were carried out, showing some positive effects on enzymatic browning at an oxygen partial pressure of $100 \mathrm{kPa}$ [97]. In addition, the combined use of high- $\mathrm{O}_{2}$ and ultraviolet irradiation had a positive and synergistic effect in minimally processed carrots, keeping global quality and reducing microbiological growth [101].

\subsection{Calcium Washing Treatments}

Calcium solutions are usually used (especially in fruits) in order to reinforce cell structures (and therefore firmness) by cross-linking with cell wall and middle lamella pectins. As explained in previous sections, PPO is highly influenced by cell integrity. Therefore, these treatments are usually related to a decrease in PPO activity and the subsequent browning. Thus, PPO activity is expected to be reduced when using calcium treatments due to the fact that cell structures are stronger, avoiding the enzyme-substrate contact. The main calcium treatment used is calcium lactate due to the fact that it does not add flavor to the produce (such ascalcium chloride, its antecessor, does) [8,102]. In the case of fresh-cut produces, it is used as a complementary treatment, especially for heat-treatments. Therefore, many studies involved the use of calcium treatments [86,103]. For instance, in the case of fresh-cut iceberg lettuce with increasing calcium lactate concentration, a decrease in PPO activity was found. However, minimal color evolution was found for a concentration of $1.5 \%$, and more concentrated solutions showed some evolution [15]. Consequently, the optimization of calcium treatments (regarding addition) is required. Depending on the salt that calcium comes from, its effect might vary especially due to the hydrogen ion concentration during the washing treatment [68]. The use of calcium citrate and ascorbate (assuring $0.4 \% \mathrm{Ca}$ at $60^{\circ} \mathrm{C}$ for $1 \mathrm{~min}$ in both cases) was studied for fresh-cut eggplant. Both of them were effective at reducing PPO activity, but the latter offered a stronger texture decay resistance [28]. The use of calcium ascorbate has been proved in fresh-cut pears, finding browning reduction probably due to o-quinones reduction by ascorbate, competing with browning substrates for the active site of pear PPO [69]. This way, there was a competition between the enzyme and the additive which resulted in a decrease in PPO activity.

\subsection{Antioxidants and Antimicrobials}

Many antioxidants or antimicrobial agents (such as ascorbic isoascorbic or citric acids) or inhibitors (such as cysteine and 4-hexylresorcinol) might be used for PPO activity delay [104]. Indeed, they can reduce microbial loads and rinse of tissue fluids, responsible for both enzymatic acceleration and microbial growth [12]. Some of the most important substances used to this purpose are ascorbic acid, citric acid or cysteine, among others, which will be explained in following subsections. 


\subsubsection{Ascorbic Acid}

Its effect might be due to $\mathrm{pH}$ decrease (under optimal $\mathrm{pH}$ for PPO, as previously explained), metal chelation and oxygen availability reduction. Its use has been proved to be effective in combination with other washing treatments or MAP in fresh-cut jackfruit [90]. On the other hand, there are studies where the effectiveness of ascorbic acid was not clear. Thus, the combined use of ascorbic acid $(0.5 \%)$ and nitric oxide $(5 \mu \mathrm{M})$ washing treatments was used in fresh-cut peaches, not showing significant effects on it during storage [10]. In addition, the role of ascorbic acid in the inhibition of PPO in different lettuce samples was studied, reducing its activity by about $90 \%$. In that sense, PPO was found to be the main enzyme related for browning, and both endogenous and exogenous ascorbic acid played an important role in PPO inhibition [64].

\subsubsection{Citric Acid}

This is a phenolase $\mathrm{Cu}$-chelating agent, and the inhibition of polyphenol oxidase was attributed to its chelating action and $\mathrm{pH}$ decrease [28]. Indeed, some authors have studied the effect of citric acid on PPO activity, carrying out some in-vitro assays. An increase in citric acid concentration might inhibit PPO. Consequently, they claim that the use of $0.1 \mathrm{M}$ citric acid might be useful for fresh-cut Chinese water chestnut if it is combined with other antioxidants [105]. Indeed, another study applied an antioxidant solution ( $0.5 \%$ citric acid, $0.5 \%$ ascorbic acid and $0.5 \%$ calcium chloride) in combination with some modified atmospheres (argon, nitrous oxide and low percentage of $\mathrm{O}_{2}$ and $\mathrm{CO}_{2}$ ) to minimally processed apples successfully, due to the fact that PPO was inhibited and metabolic activity lowered [96]. Again, the use of combined techniques might be advisable for PPO activity reduction, showing synergistic effects.

\subsubsection{Cysteine and Its Derivatives}

The thiol-containing aminoacid cysteine (an amioacid that has GRAS status) has been reported to effectively inhibit PPO-mediated enzymatic browning of fruits and vegetables, although some studies have remarked a neutral effect on PPO activity reduction (possibly due to $\mathrm{pH}$ adjustment, as explained in the following studies) whereas bioactive compounds were kept [40]. Nevertheless, three mechanisms have been reported to effectively inhibit enzymatic browning: (1) reduction of the o-quinone back to o-dihydroxyphenol. (2) direct inhibition of PPO by bounding cooper in the enzyme. (3) formation of a colorless cysquinone adduct. When cysteine is used as an inhibitor of enzymatic browning on some fruits such as pears or apples, pinkish-red colored compounds are formed due to phenol regeneration with deep color formation $[95,106]$. It was also reported that cysteine might be more effective at a neutral $\mathrm{pH}$ due to the acidity constant of the thiol group $(\mathrm{pKa}=8.33)$. Taking into account that some tissues are acidic (especially in the case of some fruits) the use of cysteine alone as an inhibitor of enzymatic browning is not effective, and consequently the use of reducing agents or a buffer at $\mathrm{pH} 7.0$ are advisable [95]. Thus, many studies have been carried out using cysteine among other washing treatments. For example, the use of a dip of $2 \%$ ascorbic acid, $1 \%$ calcium lactate and $0.5 \%$ cysteine adjusted with $\mathrm{NaOH}$ at $\mathrm{pH}=7.0$ significantly extended the shelf-life of fresh-cut pears [95]. The use of $0.5 \%$ $\mathrm{HCl} \cdot 1-$ cysteine monohydrate solution was proved in combination with a gaseous $\mathrm{ClO}_{2}$ treatment (the latter dramatically affecting visual quality, as some authors pointed out), being suitable for avoiding browning caused by the gaseous treatment but decreasing its decontamination effectiveness [107]. As explained before, $\mathrm{pH}$ not only affects PPO activity but the effectiveness of many washing treatments. Thus, as some authors have reported, $\mathrm{pH}$ plays a vital role in cysteine activity as in the case of fresh-cut artichokes, recommending neutral $\mathrm{pH}$ for the best visual quality results and the least PPO activity [25].

On the other hand, $\mathrm{N}$-acetylcysteine is specifically used as a dietary supplement, being used in order to avoid cut browning. For instance, it is worth mentioning the optimization of a washing treatment including $\mathrm{N}$-acetylcysteine in minimally processed apples. Thus, the use of $100 \mathrm{mM}$ isoascorbic acid, $5 \mathrm{mM}$ Caascorbate, $5 \mathrm{mM}$ Capropionate and 
$5 \mathrm{mM} \mathrm{N}$-acetylcysteine washing treatment on different cultivar apples was the optimum combination used in order to keep visual quality [104].

\subsubsection{Salicylic Acid}

This product could be used included in washing treatments, as the literature showed promising results when it comes to PPO control. As some authors have appointed, the use of salicylic acid (SA) in washing treatments have showed good results concerning PPO inhibition in fresh-cut chestnut, and its effect was higher with concentration (up to $10 \mathrm{mM}$ or at least $0.3 \mathrm{~g} / \mathrm{L}$, depending on the case). However, its inhibition properties are not clear yet, needing further studies [65,108].

\subsubsection{Whey Permeate}

In order to avoid chlorinated water (and other chemical treatments) due to the formation of carcinogenic compounds or other health concerns, many alternatives (especially natural products) have been studied to reduce microbial counts or improve shelf-life in fresh-cut produce. That is the case of whey permeate, which is a by-product of the dairy industry. In that sense, the use of wastes from other industries could contribute to the concept of circular economy, which is highly rated nowadays.This washing treatment has been proved to be effective when it comes to microbial growth. However, not many studies about its application in minimal processing or its effect on PPO activity have been carried out. Nevertheless, whey permeate was a suitable treatment for fresh-cut lettuce and carrot. Namely, its PPO activity inhibition was outstanding, being more effective when concentration was increased up to 3\%. Moreover, no sensory differences were found for treated samples, which is essential for a treatment to be applied in minimal processing [20]. The optimum use of whey protein concentrate in order to inhibit PPO activity was proved to be competitive $(28 \mathrm{mg} / \mathrm{L})$ in fresh-cut lettuce (60\% inhibition) even though its effect was not as effective as in the case of cysteine [109].

\subsubsection{Hydrogen Peroxide}

$\mathrm{H}_{2} \mathrm{O}_{2}$ has been used as a powerful disinfectant due to its oxidizing properties, reducing microbial counts of human pathogens. Therefore, it might be recommended especially if it is combined with complementary treatments such as browning inhibitors or calcium derivatives. Not many studies about its influence on PPO activity have been carried out. Applied on fresh-cut Chinese water chestnut, hydrogen peroxide markedly inhibited the increase in PAL and PPO activities, and a sequential increase in $\mathrm{H}_{2} \mathrm{O}_{2}$ treatments (from 0.15 to $0.9 \% w / v$ for $1 \mathrm{~min}$ ) was more effective at inhibiting PPO activity. This finding might be probably explained by the direct denaturation of PPO and PAL during this treatment [16].

\subsubsection{Ozonated Water}

Ozonated water has been applied especially to fresh-cut vegetables for sanitation purposes. Ozone has a greater effect against certain microorganisms and rapidly decomposes to oxygen, leaving no residues and causing less regulatory concern than chlorine $[8,110]$. Some studies about the effect of ozone on PPO activity have been performed. In this way, different ozonated water concentrations on fresh-cut celery were used, finding that the higher ozone concentration in water was (up to $0.18 \mathrm{ppm}$ ), the less PPO activity was found, probably due to the microbial reduction [82]. In addition, another study found similar results for fresh-cut lettuce, reducing enzymatic browning [111]. The use of ozone in CA for fresh-cut processing was checked in carrots, paying attention to PPO activity and lignification. Thus, both PPO and POD were reduced by applying $2 \% \mathrm{O}_{2}$ and $8 \% \mathrm{CO}_{2}$ after a washing treatment with ozone $(10 \mathrm{mg} / \mathrm{L})$ for $10 \mathrm{~min}$ [27]. However, its application in extending the shelf-life of fresh-cut potatoes did not seem to offer any effect on PPO activity, whereas NaturSeal and other dip treatment such assodium acid sulfate had a positive effect [112]. 


\subsubsection{Neutral Electrolyzed Oxidizing Water (NEW)}

It has been used as an alternative to prolong the shelf-life of minimally processed vegetables. It is generated by an electrolytic cell from tap water or a diluted sodium chloride solution pumped into it. Consequently, the product has a high chlorine effect among other compounds with antimicrobial effect, with a wide sterilization range and posing no threat to health and the environment [113]. Thus, some authors have studied the effect of EOW on some vegetables. That is the case of fresh-cut cabbage being undergone NEW treatment ( $45 \mathrm{mg} / \mathrm{L}$ free chlorine concentration keeping $\mathrm{pH}$ at 8.3). Thus, browning has been arrested probably due to PPO oxidization and its consequent weakening. Moreover, PPO might be inhibited by $\mathrm{NaCl}$, due to complex formation between the halide ion and cooper in the enzyme. However, before inactivating the enzyme some phenols might get oxidized, taking place some browning [83]. Another study on fresh-cut lettuce was carried out, showing more inhibition when high free chlorine concentrations $(60-120 \mathrm{mg} / \mathrm{L})$ were used, possibly on account of PPO's amino acids or disulfide bounds oxidation. However, the highest free chlorine concentration conveyed loss of turgor, needing the optimization of this parameter as in the case of many other techniques [114].

\subsubsection{Other Washing Treatments}

Many washing treatments not mentioned before have been used in minimal processing, whose relevancy should be noted. Thus, the use of $\mathrm{ClO}_{2}$ has been proved for fresh-cut processing, showing different results regarding the following aspects: reduction of the risk of foodborne infections and intoxications, decrease in microbial spoilage, preservation of fresh attitudes and nutritional quality or absence of unacceptable levels of toxic residues. In that sense, its microbiological control has been widely proved [115]. On one hand, some authors have pointed out its negative effect (in gaseous form) on visual appearance in lettuce and cabbage [107]. On the other hand, different $\mathrm{ClO}_{2}$ washing treatments $(10,50$ and $100 \mathrm{mg} / \mathrm{L}$ ) seemed to control PPO activity for fresh-cut lotus root [33]. For fresh-cut lettuce, the use of $\mathrm{ClO}_{2}(100 \mathrm{mg} / \mathrm{L})$ inhibited PPO from day 8 of storage [30]. Sodium chlorite was used in fresh-cut apples, inhibiting browning reaction and PPO activity [44]. Finally, a recent study considered chlorogenic acid as a treatment to reduce PPO activity in fresh-cut potatoes, significantly inactivating this enzyme [116].

\subsection{Edible Coatings}

Coatings of edible materials applied as a thin layer in order to improve quality of fresh-cut fruits and vegetables act as a barrier that reduces respiration and water loss. Plus, some additives can be placed in edible coatings, acting more effectively in browning inhibition or texture maintenance, reducing PPO activity in many cases $[81,117,118]$. Thus, some authors have used chitosan coatings in order to increase quality in fresh-cut produces. For example, it was applied on Chinese water chestnut, reducing PPO and phenylalanine ammonia liase (PAL) activity and therefore increasing its shelf-life [119]. The use of alginate in combination with calcium chloride was studied for apples, retarding browning probably due to PPO inhibition by calcium chloride (the latter interacting with cooper) and $\mathrm{O}_{2}$ reduction on account of the subsequent edible coating's barrier action [67]. Other edible coating used in apple was a trehalose $(0.8 \%), \mathrm{NaCl}(0.1 \%)$ and sucrose $(1.0 \%)$ solution for $5 \mathrm{~min}$. This innovative coating was able to reduce browning due to the ability to conform with polyphenol compounds, avoiding weight loss and maintaining color during storage [23]. Additionally, in minimally processed Red Delicious apples, the use of a coating consisting of tocopherol/mucilage nanoemulsion was tested, observing $65 \%$ decrease in PPO activity after 21 days of storage at $4{ }^{\circ} \mathrm{C}$ [45]. Other chitosan coatings (combined with AA and calcium chloride) were also used, being its effect on PPO activity proved in fresh-cut Fuji apples [120]. Regarding other minimally processed fruits, as in the case of fresh-cut pineapples, the combination of alginate treatment and MAP did not show PPO activity during storage nor browning evolution [121]. For fresh-cut banana, dipping the produce into chemical solution $(0.5 \%$ ascorbic acid, $2 \%$ calcium chloride and $0.75 \%$ 
cysteine) combined with carrageenan coating plus storage under controlled atmosphere $\left(3 \% \mathrm{O}_{2}\right.$ and $\left.10 \% \mathrm{CO}_{2}\right)$ showed PPO activity inhibition and therefore this method could be suitable to preserve them for up to 5 days [18]. For pears, chitosan (1\%) and its derivative carboxichitosan $(1 \%)$ was also proved in combination with sodium chlorite $(600 \mathrm{mg} / \mathrm{L})$, being the latter more effective with over 50\% PPO inhibition [55]. Finally, konjac glucomannan coating incorporated with pineapple fruit extract was used for fresh-cut rose apple fruit, being the PPO and POD activities lower than in control samples and therefore retarding browning [122]. In addition, the effect of chitosan coating and MAP on PPO activity was positively proved in fresh-cut lotus root [99]. Similar results were obtained with another edible coating based on cysteine and citric acid, applied to fresh-cut lotus root slices, inhibiting browning and microbial growth [123]. Thus, as in many other treatments covered in this review, the combination of treatments could be a suitable way to strengthen their effectiveness, showing synergistic effects. In addition, the use of natural products (which are increasingly interesting for customers) seems to become important to produce edible coatings. This way, some authors have tested the effectiveness of aloe vera gel and honey-based edible coatings to keep quality parameters in fresh-cut papaya. As a result, its combination with other chemical dips (such as ascorbic acid or vanillin) reduced PPO activity and kept global quality parameters (such as weight loss or sensory quality) during a storage period of 12 days at $4{ }^{\circ} \mathrm{C}$ [51].

\subsection{Extracts and Essential Oils}

Apart from the fact that costumers look for healthy food, further efforts have been made in order to seek natural substances that can substitute the washing treatments used nowadays. In that sense, the use of natural extracts can be a suitable way to achieve this goal. For instance, the use of onion extracts on banana PPO activity during ripening was studied, showing a significant inhibitory effect when the extract was heated at $100{ }^{\circ} \mathrm{C}$ for $10 \mathrm{~min}$ [124]. In addition, more recent research has pointed out the effectiveness of mulberry extracts on improving the quality of fresh-cut cantaloupe during storage. However, although exogenous phenolic compounds can inhibit the enzyme activity of PPO, phenolic substances included in the extract in study, such as gallic, chlorogenic or caffeic acid could also accelerate enzymatic browning reaction with PPO of cantaloupe, requiring further study to investigate the mechanism of these extracts [125]. On the other hand, especially due to their antimicrobial activity, essential oils have become popular. However, the impact of these substances on food properties should be taken into account, as both positive and negative effects can appear, requiring an optimum concentration [12,126]. Essential oils have been widely used in minimal processing. Thus, for minimally processed lettuce, green tea extract (GT) was used. High GT concentration (5 to $10 \mathrm{~g} / \mathrm{L}$ ) showed lower PPO activity levels in fresh-cut lettuce. However, the extra-supply of phenols by GT might imply some browning. As a result, a lower concentration $(2.5 \mathrm{~g} / \mathrm{L})$ was recommended on account of the high browning produced when GT was used at high concentrations [22]. In addition, the effect of essential oils of Origanum L. (a medicinal and aromatic plant) on fresh-cut mushrooms was studied, concluding that its combined use with suitable storage conditions could reduce PPO activity and its subsequent adverse effects [35]. As expected, the combined use of conservative techniques could be suitable when using extracts or essential oils. For instance, edible coatings and extracts might be useful as in the case of minimally processed pears, proving the use of oxygen pre-treatment, chitosan coating and rosemary extracts as an effective way to retain PPO activity [54]. Another interesting aspect of natural extracts or essential oils is the fact that some of them can be obtained from wastes which are difficult to be managed, which makes them valuable, contributing to circular economy. For example, recent studies have pointed out that the use of extracts from strawberry by-products (rich in phenolic compounds) could reduce PPO activity in apples [46]. 


\subsection{Electromagnetic Radiations/Ultrasonication}

Due to its feasibility of use, different irradiation systems have been used for fruits and vegetables, both for entire and fresh-cut produce. They might be used directly on food surface or in water (in order to reduce microbiological growth and therefore re-use it). The following sections explain some of these techniques in detail.

\subsubsection{Gamma Irradiation}

Irradiation has been proved to be effective for inactivation of microorganisms, especially in vegetables such as lettuce, onions or carrots, increasing their shelf-life. Its effectiveness has also been studied for fresh-cut produce, where the decrease in PPO activity and microbial growth are always related, as explained in previous sections, possibly due to their common starting point when it comes to the degradation of fresh-cut produces (cell lysis).In this case, gamma-ray irradiation was effective for reducing both microbial growth and PPO activity (especially at the beginning of storage) in fresh-cut celery, with $1.0 \mathrm{kGy}$ being the most effective dose and keeping global quality of this product up to 9 days of storage [127]. Similar results were found in fresh-cut lettuce, with $1.0 \mathrm{kGy}$ being the most suitable dose to keep global quality, including vitamin C content or PPO activity [128]. In the case of fresh-cut red beet, low doses of gamma irradiation (1.0 and $2.0 \mathrm{kGy}$ ) were used, and the latter showed a PPO activity increase [41]. As a consequence, in most of these studies, low irradiation doses are recommended (pointing out, again, the parameter optimization for each case, as in the case of abovementioned treatments), andadditional treatments are suggested in order to control tissue senescence, being effective especially at the beginning of storage.

\subsubsection{Pulsed Light}

It is a promising technique used for the rapid inactivation of pathogenic and spoilage microorganisms in food. Thus, it implies the use of intense pulses of short duration and a broad spectrum to ensure microbial inactivation on surface. A study about light pulse and it application on minimally processed mushrooms was carried out, finding a $4.8 \mathrm{~J} / \mathrm{cm}^{2}$ dose suitable for fresh-cut mushrooms, reducing browning index and PPO activity. However, higher doses might not be advisable due to possible textural damages and dehydration [34]

\subsubsection{High Intensity Light (HIL)}

HIL is assumed to cause non-reversible structural changes in PPO, which results in enzyme inactivation. Thus, direct photo-oxidation of absorbing residues of PPO amino acids to form radicals might be the main reason of inactivation. Therefore, the use of this technique in fresh-cut lettuce was assessed, finding satisfactory results. Thus, in HIL samples (undergoing light intensities from 500 to $2500 \mathrm{~lx}$ ), PPO activity was lower than in samples stored in darkness, keeping visual quality during storage [129].

\subsubsection{Ultraviolet Treatments}

The use of UV in fresh-cut fruits and vegetables is well known, especially for microbiological control due to its germicidal effect. However, not many studies on minimally processed produce have been carried out yet. According to some authors, some color decay might be found, probably due to higher enzymatic activity on account of loss of compartmentalization, as it was found for fresh-cut apple, especially for high doses. Thus, additional treatments (such as the use of ascorbic acid and calcium lactate) are required [130].

\subsubsection{Ultrasonication}

Ultrasound (US) might cause enzyme inactivation by cell lysis due to vibration energy, which produces cavitation bubbles and temporarily generates spots of high pressure and temperature when imploded. Thus, its use might be suitable especially when combined with antioxidant treatments (normally included in washing treatments), just as in the case 
of fresh-cut apples. Specifically, PPO activity was reduced by combining US (40 kHz) and ascorbic acid (1\%), pointing out the fact that the individual application of these treatments was not effective at inactivating enzyme activity [43]. Other recent study was focused on the suitability of this technique combined with ascorbic acid and citric acid for fresh-cut potatoes, showing around $40 \%$ decrease in PPO activity in treated samples, compared to control samples [38].

\subsection{High-Pressure Carbon Dioxide (HPCD) and Argon (HPA)}

Even though HPCD has not been widely used for fresh-cut processing yet (which has been successfully used in peach and carrot juice, with PPO inhibition [131]), this novel technique might be suitable for microorganism and enzyme inactivation in minimally processed produce. However, some authors have pointed out the increase of PPO and POD activity in fresh-cut carrots when this technique was applied (at 1.5, 3 or $5 \mathrm{MPa}$ ), probably due to protein dissociation, interactions with other constituents in the extract or from the release of membrane-bound enzymes. Therefore, further studies about HPCD parameters are needed [26]. HPA has been proved in fresh-cut apples, finding de-compartmentalization and PPO and phenols delocalization as main causes in order to explain the increase of browning [132].

\section{Conclusions and Future Needs}

An overview about PPO has been accomplished, trying to include the main aspects when minimal processing is concerned. Thus, researchers have mainly focused on the following points:

- The importance of pre-harvest conditions on PPO activity (among other enzymes) and quality deterioration. In that sense, many authors have pointed out the strong influence of these conditions in many aspects related to PPO activity, such as PPO or polyphenol content, firmness, etc.

- The specific characterization of cultivars in order to predict their performance during minimal processing, specifically regarding PPO and polyphenol content. This way, many authors have selected the most suitable fruit or vegetable cultivars to obtain high-quality fresh-cut produce.

- Selection and optimization of treatments to keep quality of minimally processed fruits or vegetables. As explained in previous sections, many works have pointed out the importance of using optimum conditions for each treatment (for instance, the right $\%$ $\mathrm{CO}_{2}$ percentage in MAP or the suitable temperature and time treatment for blanching), both to improve the effectiveness of the treatment to decrease PPO activity and to avoid undesirable effects. It should have noted that, in some cases (especially when different conservation techniques are combined), an intermediary solution should be found.

- The combined use of conservative techniques. As many studies have proved, the use of two or three techniques can present additive or synergistic effects when it comes to PPO inhibition, due to the direct inhibition of the enzyme or indirect positive effects (such as microbial control or turgence promotion, which also results in a decrease in PPO activity). In that sense, the MAP and washing treatments seem to be suitable techniques to be combined with other innovative ones, such as irradiation, the use of active packaging, etc.

- Sustainability and circular economy. In most cases, optimization of operating parameters in most conservative techniques is necessary, not only in order to increase the effectiveness of each method, but also to reduce costs and develop industrial-scale strategies. Thus, the use of hurdle technologies can contribute to mild conditions, implying lower costs (especially concerning temperature or reagent addition). Another interesting aspect is the possible contribution to circular economy, by using some wastes to obtain interesting product for minimal processing (such as natural extracts or essential oils, among others). 
In conclusion, $\mathrm{PPO}$ is an important concern for fresh-cut processing, being the developing key for new inhibitory treatments in order to contribute to shelf-life increase. In addition, many studies have been carried out to get further knowledge about PPO's mechanism. Indeed, due to some authors' controversy and probably because of the several matrixes found in fruit and vegetables, the relationship between PPO activity and browning should be cleared up and yet further studies should focus on PPO behavior depending on food matrix.

Additionally, further studies should be carried out in order to perfect the parameters of some trendy techniques such as HPCD, US or UV treatments.

Thus, the use of hurdle technology is a promising technique in order to control PPO activity without compromising other quality properties in food. In this case, the use of UV or Gamma radiation or US might be a complementary ally in order to preserve visual quality in fresh-cut produce, as well as the use of mild treatment to avoid any quality change in these products.

Funding: This research received no external funding.

Institutional Review Board Statement: Not applicable.

Informed Consent Statement: Not applicable.

Data Availability Statement: Data sharing not applicable as no datasets were generated or analysed during this study.

Conflicts of Interest: The author declares no conflict of interest.

\section{Nomenclature}

$\begin{array}{ll}\text { AA } & \text { Ascorbic Acid } \\ \text { CA } & \text { Controlled atmosphere } \\ \text { DOPAC } & \text { 3,4-Dihydroxyphenylacetic acid } \\ \text { EDTA } & \text { Ethylenediaminetetraacetic acid } \\ \text { GT } & \text { Green tea extract } \\ \text { HIL } & \text { High intensity light } \\ \text { HPA } & \text { High pressure argon } \\ \text { HPCD } & \text { High pressure carbon dioxide } \\ \text { MBTH } & \text { 3-Methyl-2-Benzothiazolinone Hydrazone } \\ \text { MAP } & \text { Modified atmosphere packaging } \\ \text { NEW } & \text { Neutral electrolyzed oxidizing water } \\ \text { POD } & \text { Peroxidase } \\ \text { PAL } & \text { Phenylalanine ammonia lyase } \\ \text { PMSF } & \text { Phenylmethylsulphonyl fluoride } \\ \text { PPO } & \text { Polyphenol oxidase } \\ \text { PVP } & \text { Polyvinyl pyrrolidone } \\ \text { PVPP } & \text { Polyvinyl polypyrrolidone } \\ \text { SA } & \text { Salicylic acid } \\ \text { US } & \text { Ultrasound } \\ \text { UV } & \text { Ultraviolet }\end{array}$

\section{References}

1. Giovenzana, V.; Casson, A.; Beghi, R.; Pampuri, A.; Fiorindo, I.; Tugnolo, A.; Guidetti, R. Evaluation of consumer domestic habits on the environmental impact of ready-to-eat and minimally processed fresh-cut lamb's lettuce. Sustain. Prod. Consum. 2021, 28, 925-935. [CrossRef]

2. Baselice, A.; Colantuoni, F.; Lass, D.A.; Nardone, G.; Stasi, A. Trends in EU consumers' attitude towards fresh-cut fruit and vegetables. Food Qual. Prefer. 2017, 59, 87-96. [CrossRef]

3. Nogales-Delgado, S.; Fuentes-Pérez, M.C.; Bohoyo-Gil, D. Cultivar characterization of stone fruits for their minimal processing. J. Food Sci. Technol. 2015, 52. [CrossRef]

4. Fuentes-Pérez, M.D.C.; Nogales-Delgado, S.; Ayuso, M.C.; Bohoyo-Gil, D. Different peach cultivars and their suitability for minimal processing. Czech J. Food Sci. 2014, 32, 2193-2201. [CrossRef] 
5. Nogales-Delgado, S.; Fernández-León, A.M.; Delgado-Adámez, J.; Hernández-Méndez, M.T.; Bohoyo Gil, D. Effects of several sanitisers for improving quality attributes of minimally processed fragaria vesca strawberry. Czech J. Food Sci. 2013, 31, 49-54. [CrossRef]

6. Nogales-Delgado, S.; Fuentes-Pérez, M.C.; Ayuso-Yuste, C.; Bohoyo-Gil, D. Study of different nectarine cultivars and their suitability for fresh-cut processing. Int. J. Food Sci. Technol. 2014, 49, 114-120. [CrossRef]

7. SCOPUS Scopus Preview. Available online: https://www.scopus.com/home.uri (accessed on 30 July 2021).

8. Rico, D.; Martín-Diana, A.B.; Barat, J.M.; Barry-Ryan, C. Extending and measuring the quality of fresh-cut fruit and vegetables: A review. Trends Food Sci. Technol. 2007, 18, 373-386. [CrossRef]

9. Hodges, D.M.; Toivonen, P.M.A. Quality of fresh-cut fruits and vegetables as affected by exposure to abiotic stress. Postharvest Biol. Technol. 2008, 48, 155-162. [CrossRef]

10. Li-Qin, Z.; Jie, Z.; Shu-Hua, Z.; Lai-Hui, G. Inhibition of browning on the surface of peach slices by short-term exposure to nitric oxide and ascorbic acid. Food Chem. 2009, 114, 174-179. [CrossRef]

11. Toivonen, P.M.A.; Brummell, D.A. Biochemical bases of appearance and texture changes in fresh-cut fruit and vegetables. Postharvest Biol. Technol. 2008, 48, 1-14. [CrossRef]

12. Oms-Oliu, G.; Rojas-Graü, M.A.; González, L.A.; Varela, P.; Soliva-Fortuny, R.; Hernando, M.I.H.; Munuera, I.P.; Fiszman, S.; Martín-Belloso, O. Recent approaches using chemical treatments to preserve quality of fresh-cut fruit: A review. Postharvest Biol. Technol. 2010, 57, 139-148. [CrossRef]

13. Moreno, J.; Chiralt, A.; Escriche, I.; Serra, J.A. Effect of blanching/osmotic dehydration combined methods on quality and stability of minimally processed strawberries. Food Res. Int. 2000, 33, 609-616. [CrossRef]

14. Cefola, M.; D’Antuono, I.; Pace, B.; Calabrese, N.; Carito, A.; Linsalata, V.; Cardinali, A. Biochemical relationships and browning index for assessing the storage suitability of artichoke genotypes. Food Res. Int. 2012, 48, 397-403. [CrossRef]

15. Martin-Diana, A.B.; Rico, D.; Barry-Ryan, C.; Frias, J.M.; Mulcahy, J.; Henehan, G.T.M. Calcium lactate washing treatments for salad-cut Iceberg lettuce: Effect of temperature and concentration on quality retention parameters. Food Res. Int. 2005, 38, 729-740. [CrossRef]

16. Peng, L.; Yang, S.; Li, Q.; Jiang, Y.; Joyce, D.C. Hydrogen peroxide treatments inhibit the browning of fresh-cut Chinese water chestnut. Postharvest Biol. Technol. 2008, 47, 260-266. [CrossRef]

17. Rico, D.; Martín-Diana, A.B.; Barry-Ryan, C.; Frías, J.M.; Henehan, G.T.M.; Barat, J.M. Optimisation of steamer jet-injection to extend the shelflife of fresh-cut lettuce. Postharvest Biol. Technol. 2008, 48, 431-442. [CrossRef]

18. Bico, S.L.S.; Raposo, M.F.J.; Morais, R.M.S.C.; Morais, A.M.M.B. Combined effects of chemical dip and/or carrageenan coating and/or controlled atmosphere on quality of fresh-cut banana. Food Control 2009, 20, 508-514. [CrossRef]

19. Chung, H.S.; Moon, K.D. Browning characteristics of fresh-cut "Tsugaru" apples as affected by pre-slicing storage atmospheres. Food Chem. 2009, 114, 1433-1437. [CrossRef]

20. Martin-Diana, A.B.; Rico, D.; Frias, J.; Mulcahy, J.; Henehan, G.T.M.; Barry-Ryan, C. Whey permeate as a bio-preservative for shelf life maintenance of fresh-cut vegetables. Innov. Food Sci. Emerg. Technol. 2006, 7, 112-123. [CrossRef]

21. Degl'Innocenti, E.; Pardossi, A.; Tognoni, F.; Guidi, L. Physiological basis of sensitivity to enzymatic browning in "lettuce", "escarole" and "rocket salad" when stored as fresh-cut products. Food Chem. 2007, 104, 209-215. [CrossRef]

22. Martín-Diana, A.B.; Rico, D.; Barry-Ryan, C. Green tea extract as a natural antioxidant to extend the shelf-life of fresh-cut lettuce. Innov. Food Sci. Emerg. Technol. 2008, 9, 593-603. [CrossRef]

23. Albanese, D.; Cinquanta, L.; Di Matteo, M. Effects of an innovative dipping treatment on the cold storage of minimally processed Annurca apples. Food Chem. 2007, 105, 1054-1060. [CrossRef]

24. Panadare, D.; Rathod, V.K. Extraction and purification of polyphenol oxidase: A review. Biocatal. Agric. BioTechnol. 2018, 14, 431-437. [CrossRef]

25. Cabezas-Serrano, A.B.; Amodio, M.L.; Colelli, G. Effect of solution pH of cysteine-based pre-treatments to prevent browning of fresh-cut artichokes. Postharvest Biol. Technol. 2013, 75, 17-23. [CrossRef]

26. $\mathrm{Bi}, \mathrm{X} . ; \mathrm{Wu}, \mathrm{J} . ; \mathrm{Zhang}$, Y.; Xu, Z.; Liao, X. High pressure carbon dioxide treatment for fresh-cut carrot slices. Innov. Food Sci. Emerg. Technol. 2011, 12, 298-304. [CrossRef]

27. Chauhan, O.P.; Raju, P.S.; Ravi, N.; Singh, A.; Bawa, A.S. Effectiveness of ozone in combination with controlled atmosphere on quality characteristics including lignification of carrot sticks. J. Food Eng. 2011, 102, 43-48. [CrossRef]

28. Barbagallo, R.N.; Chisari, M.; Caputa, G. Effects of calcium citrate and ascorbate as inhibitors of browning and softening in minimally processed "Birgah" eggplants. Postharvest Biol. Technol. 2012, 73, 107-114. [CrossRef]

29. Mishra, B.B.; Gautam, S.; Sharma, A. Browning of fresh-cut eggplant: Impact of cutting and storage. Postharvest Biol. Technol. 2012, 67, 44-51. [CrossRef]

30. Chen, Z.; Zhu, C.; Zhang, Y.; Niu, D.; Du, J. Effects of aqueous chlorine dioxide treatment on enzymatic browning and shelf-life of fresh-cut asparagus lettuce (Lactuca sativa L.). Postharvest Biol. Technol. 2010, 58, 232-238. [CrossRef]

31. Chisari, M.; Todaro, A.; Barbagallo, R.N.; Spagna, G. Salinity effects on enzymatic browning and antioxidant capacity of fresh-cut baby Romaine lettuce (Lactuca sativa L. cv. Duende). Food Chem. 2010, 119, 1502-1506. [CrossRef]

32. Luna, M.C.; Tudela, J.A.; Martínez-Sánchez, A.; Allende, A.; Marín, A.; Gil, M.I. Long-term deficit and excess of irrigation influences quality and browning related enzymes and phenolic metabolism of fresh-cut iceberg lettuce (Lactuca sativa L.). Postharvest Biol. Technol. 2012, 73, 37-45. [CrossRef] 
33. Du, J.; Fu, Y.; Wang, N. Effects of aqueous chlorine dioxide treatment on browning of fresh-cut lotus root. LWT Food Sci. Technol. 2009, 42, 654-659. [CrossRef]

34. Oms-Oliu, G.; Aguiló-Aguayo, I.; Martín-Belloso, O.; Soliva-Fortuny, R. Effects of pulsed light treatments on quality and antioxidant properties of fresh-cut mushrooms (Agaricus bisporus). Postharvest Biol. Technol. 2010, 56, 216-222. [CrossRef]

35. Tanhaş, E.; Martin, E.; Korucu, E.N.; Dirmenci, T. Effect of aqueous extract, hydrosol, and essential oil forms of some endemic Origanum L. (Lamiaceae) taxa on polyphenol oxidase activity in fresh-cut mushroom samples. J. Food Process. Preserv. 2020, 44, e14726. [CrossRef]

36. Cabezas-Serrano, A.B.; Amodio, M.L.; Cornacchia, R.; Rinaldi, R.; Colelli, G. Suitability of five different potato cultivars (Solanum tuberosum L.) to be processed as fresh-cut products. Postharvest Biol. Technol. 2009, 53, 138-144. [CrossRef]

37. Zhang, Z.; Yao, Y.; Shi, Q.; Zhao, J.; Fu, H.; Wang, Y. Effects of radio-frequency-assisted blanching on the polyphenol oxidase, microstructure, physical characteristics, and starch content of potato. LWT 2020, 125, 109357. [CrossRef]

38. Li, L.; Bai, J.; Wu, M.; Zhao, M.; Wang, R.; Guo, M.; Liu, H.; Liu, T. Studies on browning inhibition technology and mechanisms of fresh-cut potato. J. Food Process. Preserv. 2017, 41, 1-8. [CrossRef]

39. Li, J.; Wang, H.; Lu, Y.; Mao, T.F.; Xiong, J.; He, S.L.; Liu, H. Inhibitory effect of tartary buckwheat seedling extracts and associated flavonoid compounds on the polyphenol oxidase activity in potatoes (Solanum tuberosum L.). J. Integr. Agric. 2019, 18, $2173-2182$. [CrossRef]

40. Preczenhak, A.P.; Orsi, B.; Lima, G.P.P.; Tezotto-Uliana, J.V.; Minatel, I.O.; Kluge, R.A. Cysteine enhances the content of betalains and polyphenols in fresh-cut red beet. Food Chem. 2019, 286, 600-607. [CrossRef]

41. Latorre, M.E.; Narvaiz, P.; Rojas, A.M.; Gerschenson, L.N. Effects of gamma irradiation on bio-chemical and physico-chemical parameters of fresh-cut red beet (Beta vulgaris L. var. conditiva) root. J. Food Eng. 2010, 98, 178-191. [CrossRef]

42. Barbagallo, R.N.; Chisari, M.; Patané, C. Polyphenol oxidase, total phenolics and ascorbic acid changes during storage of minimally processed "California Wonder" and "Quadrato d'Asti" sweet peppers. LWT Food Sci. Technol. 2012, 49, 192-196. [CrossRef]

43. Jang, J.H.; Moon, K.D. Inhibition of polyphenol oxidase and peroxidase activities on fresh-cut apple by simultaneous treatment of ultrasound and ascorbic acid. Food Chem. 2011, 124, 444-449. [CrossRef]

44. Luo, Y.; Lu, S.; Zhou, B.; Feng, H. Dual effectiveness of sodium chlorite for enzymatic browning inhibition and microbial inactivation on fresh-cut apples. LWT Food Sci. Technol. 2011, 44, 1621-1625. [CrossRef]

45. Zambrano-Zaragoza, M.L.; Gutiérrez-Cortez, E.; Del Real, A.; González-Reza, R.M.; Galindo-Pérez, M.J.; Quintanar-Guerrero, D. Fresh-cut Red Delicious apples coating using tocopherol/mucilage nanoemulsion: Effect of coating on polyphenol oxidase and pectin methylesterase activities. Food Res. Int. 2014, 62, 974-983. [CrossRef]

46. Villamil-Galindo, E.; Van de Velde, F.; Piagentini, A.M. Extracts from strawberry by-products rich in phenolic compounds reduce the activity of apple polyphenol oxidase. LWT 2020, 133, 110097. [CrossRef]

47. Teixeira, G.H.A.; Durigan, J.F.; Alves, R.E.; O'Hare, T.J. Use of modified atmosphere to extend shelf life of fresh-cut carambola (Averrhoa carambola L. cv. Fwang Tung). Postharvest Biol. Technol. 2007, 44, 80-85. [CrossRef]

48. Teixeira, G.H.A.; Durigan, J.F.; Ferraudo, A.S.; Alves, R.E.; O'Hare, T.J. Multivariate analysis of fresh-cut carambola slices stored under different temperatures. Postharvest Biol. Technol. 2012, 63, 91-97. [CrossRef]

49. Kanjanapongkul, K.; Baibua, V. Effects of ohmic pasteurization of coconut water on polyphenol oxidase and peroxidase inactivation and pink discoloration prevention. J. Food Eng. 2021, 292, 110268. [CrossRef]

50. Aquino-Bolaños, E.N.; Mercado-Silva, E. Effects of polyphenol oxidase and peroxidase activity, phenolics and lignin content on the browning of cut jicama. Postharvest Biol. Technol. 2004, 33, 275-283. [CrossRef]

51. Kuwar, U.; Sharma, S.; Tadapaneni, V.R.R. Aloe Vera Gel and Honey-Based Edible Coatings Combined with Chemical Dip as a Safe Means for Quality Maintenance and Shelf Life Extension of Fresh-Cut Papaya. J. Food Qual. 2015, 38, 347-358. [CrossRef]

52. Koukounaras, A.; Diamantidis, G.; Sfakiotakis, E. The effect of heat treatment on quality retention of fresh-cut peach. Postharvest Biol. Technol. 2008, 48, 30-36. [CrossRef]

53. Serra, S.; Anthony, B.; Masia, A.; Giovannini, D.; Musacchi, S. Determination of Biochemical Composition in Peach by Di ff erent Flesh Color and Textural Typologies. Foods 2020, 9, 1452. [CrossRef]

54. Xiao, C.; Zhu, L.; Luo, W.; Song, X.; Deng, Y. Combined action of pure oxygen pretreatment and chitosan coating incorporated with rosemary extracts on the quality of fresh-cut pears. Food Chem. 2010, 121, 1003-1009. [CrossRef]

55. Xiao, Z.; Luo, Y.; Luo, Y.; Wang, Q. Combined effects of sodium chlorite dip treatment and chitosan coatings on the quality of fresh-cut d'Anjou pears. Postharvest Biol. Technol. 2011, 62, 319-326. [CrossRef]

56. Martín-Diana, A.B.; Rico, D.; Barry-Ryan, C.; Frías, J.M.; Henehan, G.T.M.; Barat, J.M. Efficacy of steamer jet-injection as alternative to chlorine in fresh-cut lettuce. Postharvest Biol. Technol. 2007, 45, 97-107. [CrossRef]

57. Yingsanga, P.; Srilaong, V.; Kanlayanarat, S.; Noichinda, S.; McGlasson, W.B. Relationship between browning and related enzymes (PAL, PPO and POD) in rambutan fruit (Nephelium lappaceum Linn.) cvs. Rongrien and See-Chompoo. Postharvest Biol. Technol. 2008, 50, 164-168. [CrossRef]

58. Ayaz, F.A.; Demir, O.; Torun, H.; Kolcuoglu, Y.; Colak, A. Characterization of polyphenoloxidase (PPO) and total phenolic contents in medlar (Mespilus germanica L.) fruit during ripening and over ripening. Food Chem. 2008, 106, 291-298. [CrossRef]

59. Mayer, A.M. Polyphenol oxidases in plants and fungi: Going places? A review. Phytochemistry 2006, 67, 2318-2331. [CrossRef] 
60. Han, Q.; Liu, F.; Hao, Y.; Ni, Y. Characterization of membrane-bound polyphenol oxidase from Granny Smith apple (Malus $\times$ domestica Borkh.). Int. J. Biol. Macromol. 2020, 158, 977-984. [CrossRef]

61. Scuderi, D.; Restuccia, C.; Chisari, M.; Barbagallo, R.N.; Caggia, C.; Giuffrida, F. Salinity of nutrient solution influences the shelf-life of fresh-cut lettuce grown in floating system. Postharvest Biol. Technol. 2011, 59, 132-137. [CrossRef]

62. Debelo, H.; Li, M.; Ferruzzi, M.G. Processing influences on food polyphenol profiles and biological activity. Curr. Opin. Food Sci. 2020, 32, 90-102. [CrossRef]

63. Dovene, A.K.; Wang, L.; Bokhary, S.U.F.; Madebo, M.P.; Zheng, Y.; Jin, P. Eff ect of Cutting Styles on Quality and Antioxidant Activity of Stored Fresh-Cut Sweet Potato. Foods Artic. 2019, 8, 674.

64. Landi, M.; Degl'Innocenti, E.; Guglielminetti, L.; Guidi, L. Role of ascorbic acid in the inhibition of polyphenol oxidase and the prevention of browning in different browning-sensitive Lactuca sativa var. capitata (L.) and Eruca sativa (Mill.) stored as fresh-cut produce. J. Sci. Food Agric. 2013, 93, 1814-1819. [CrossRef] [PubMed]

65. Peng, L.; Jiang, Y. Exogenous salicylic acid inhibits browning of fresh-cut Chinese water chestnut. Food Chem. 2006, 94, 535-540. [CrossRef]

66. Abreu, M.; Beirão-da-Costa, S.; Gonçalves, E.M.; Beirão-da-Costa, M.L.; Moldão-Martins, M. Use of mild heat pre-treatments for quality retention of fresh-cut "Rocha" pear. Postharvest Biol. Technol. 2003, 30, 153-160. [CrossRef]

67. Olivas, G.I.; Mattinson, D.S.; Barbosa-Cánovas, G.V. Alginate coatings for preservation of minimally processed “Gala” apples. Postharvest Biol. Technol. 2007, 45, 89-96. [CrossRef]

68. Gomes, M.H.; Fundo, J.F.; Santos, S.; Amaro, A.L.; Almeida, D.P.F. Hydrogen ion concentration affects quality retention and modifies the effect of calcium additives on fresh-cut "Rocha" pear. Postharvest Biol. Technol. 2010, 58, 239-246. [CrossRef]

69. Gomes, M.H.; Fundo, J.F.; Poças, M.F.; Almeida, D.P.F. Quality changes in fresh-cut "Rocha" pear as affected by oxygen levels in modified atmosphere packaging and the $\mathrm{pH}$ of antibrowning additive. Postharvest Biol. Technol. 2012, 74, 62-70. [CrossRef]

70. Gancarz, M. At harvest prediction of the susceptibility of potato varieties to blackspot after impact over long-term storage. Postharvest Biol. Technol. 2018, 142, 93-98. [CrossRef]

71. Krochmal-Marczak, B.; Sawicka, B.; Krzysztofik, B.; Danilčenko, H.; Jariene, E. The effects of temperature on the quality and storage stalibity of sweet potato (Ipomoea batatas L. [Lam]) grown in Central Europe. Agronomy 2020, 10, 1665. [CrossRef]

72. Lufu, R.; Ambaw, A.; Opara, U.L. Water loss of fresh fruit: Influencing pre-harvest, harvest and postharvest factors. Sci. Hortic. 2020, 272, 109519. [CrossRef]

73. Grudzińska, M.; Boguszewska-Mańkowska, D.; Zarzyńska, K. Drought stress during the growing season: Changes in reducing sugars, starch content and respiration rate during storage of two potato cultivars differing in drought sensitivity. J. Agron. Crop Sci. 2021, 1-12. [CrossRef]

74. Caleb, O.J.; Fawole, O.A.; Mphahlele, R.R.; Opara, U.L. Impact of preharvest and postharvest factors on changes in volatile compounds of pomegranate fruit and minimally processed arils-Review. Sci. Hortic. 2015, 188, 106-114. [CrossRef]

75. Marques Silva, F.V.; Sulaiman, A. Polyphenoloxidase in Fruit and Vegetables: Inactivation by Thermal and Non-thermal Processes; Melton, L., Shahidi, F., Varelis, P.B.T.-E., Eds.; Academic Press: Oxford, UK, 2019; pp. 287-301. ISBN 978-0-12-814045-1.

76. Mostafidi, M.; Sanjabi, M.R.; Shirkhan, F.; Zahedi, M.T. A review of recent trends in the development of the microbial safety of fruits and vegetables. Trends Food Sci. Technol. 2020, 103, 321-332. [CrossRef]

77. Ma, L.; Zhang, M.; Bhandari, B.; Gao, Z. Recent developments in novel shelf life extension technologies of fresh-cut fruits and vegetables. Trends Food Sci. Technol. 2017, 64, 23-38. [CrossRef]

78. Ukuku, D.O.; Geveke, D.J.; Chau, L.; Niemira, B.A. Microbial safety and overall quality of cantaloupe fresh-cut pieces prepared from whole fruit after wet steam treatment. Int. J. Food Microbiol. 2016, 231, 86-92. [CrossRef] [PubMed]

79. Putnik, P.; Roohinejad, S.; Greiner, R.; Granato, D.; Bekhit, A.E.D.A.; Bursać Kovačević, D. Prediction and modeling of microbial growth in minimally processed fresh-cut apples packaged in a modified atmosphere: A review. Food Control 2017, 80, 411-419. [CrossRef]

80. Giannakourou, M.C.; Tsironi, T.N. Application of Processing and Packaging Hurdles for Fresh-Cut Fruits and Vegetables Preservation. Foods 2021, 10, 830. [CrossRef]

81. Maringgal, B.; Hashim, N.; Mohamed Amin Tawakkal, I.S.; Muda Mohamed, M.T. Recent advance in edible coating and its effect on fresh/fresh-cut fruits quality. Trends Food Sci. Technol. 2020, 96, 253-267. [CrossRef]

82. Zhang, L.; Lu, Z.; Yu, Z.; Gao, X. Preservation of fresh-cut celery by treatment of ozonated water. Food Control 2005, 16, 279-283. [CrossRef]

83. Gómez-López, V.M.; Ragaert, P.; Ryckeboer, J.; Jeyachchandran, V.; Debevere, J.; Devlieghere, F. Shelf-life of minimally processed cabbage treated with neutral electrolysed oxidising water and stored under equilibrium modified atmosphere. Int. J. Food Microbiol. 2007, 117, 91-98. [CrossRef]

84. Tinello, F.; Lante, A. Recent advances in controlling polyphenol oxidase activity of fruit and vegetable products. Innov. Food Sci. Emerg. Technol. 2018, 50, 73-83. [CrossRef]

85. Iqbal, A.; Murtaza, A.; Hu, W.; Ahmad, I.; Ahmed, A.; Xu, X. Activation and inactivation mechanisms of polyphenol oxidase during thermal and non-thermal methods of food processing. Food Bioprod. Process. 2019, 117, 170-182. [CrossRef]

86. Del Valle, J.M.; Aránguiz, V.; Léon, H. Effects of blanching and calcium infiltration on PPO activity, texture, microstructure and kinetics of osmotic dehydration of apple tissue. Food Res. Int. 1998, 31, 557-569. [CrossRef] 
87. Shrestha, L.; Kulig, B.; Moscetti, R.; Massantini, R.; Pawelzik, E.; Hensel, O.; Sturm, B. Optimisation of physical and chemical treatments to control browning development and enzymatic activity on fresh-cut apple slices. Foods 2020, 9, 76. [CrossRef] [PubMed]

88. Luo, Z.; Li, D.; Xie, J.; Feng, S.; Wang, Y. Effects of Heat Treatment on Quality and Browning of Fresh-Cut Sugarcane. J. Food Process. Preserv. 2015, 39, 688-696. [CrossRef]

89. Oliveira, M.; Abadias, M.; Usall, J.; Torres, R.; Teixidó, N.; Viñas, I. Application of modified atmosphere packaging as a safety approach to fresh-cut fruits and vegetables-A review. Trends Food Sci. Technol. 2015, 46, 13-26. [CrossRef]

90. Saxena, A.; Bawa, A.S.; Raju, P.S. Phytochemical changes in fresh-cut jackfruit (Artocarpus heterophyllus L.) bulbs during modified atmosphere storage. Food Chem. 2009, 115, 1443-1449. [CrossRef]

91. Wang, D.; Li, D.; Xu, Y.; Li, L.; Belwal, T.; Zhang, X.; Luo, Z. Elevated $\mathrm{CO}_{2}$ alleviates browning development by modulating metabolisms of membrane lipids, proline, and GABA in fresh-cut Asian pear fruit. Sci. Hortic. 2021, 281, 109932. [CrossRef]

92. Wang, D.; Li, W.; Li, D.; Li, L.; Luo, Z. Effect of high carbon dioxide treatment on reactive oxygen species accumulation and antioxidant capacity in fresh-cut pear fruit during storage. Sci. Hortic. 2021, 281, 109925. [CrossRef]

93. You, Y.; Jiang, Y.; Duan, X.; Su, X.; Song, L.; Liu, H.; Sun, J.; Yang, H. Browning inhibition and quality maintenance of fresh-cut chinese water chestnut by anoxia treatment. J. Food Process. Preserv. 2007, 31, 595-606. [CrossRef]

94. Thivya, P.; Bhosale, Y.K.; Anandakumar, S.; Hema, V.; Sinija, V.R. Development of active packaging film from sodium alginate/carboxymethyl cellulose containing shallot waste extracts for anti-browning of fresh-cut produce. Int. J. Biol. Macromol. 2021, 188, 790-799. [CrossRef]

95. Gorny, J.R.; Hess-Pierce, B.; Cifuentes, R.A.; Kader, A.A. Quality changes in fresh-cut pear slices as affected by controlled atmospheres and chemical preservatives. Postharvest Biol. Technol. 2002, 24, 271-278. [CrossRef]

96. Rocculi, P.; Romani, S.; Dalla Rosa, M. Evaluation of physico-chemical parameters of minimally processed apples packed in non-conventional modified atmosphere. Food Res. Int. 2004, 37, 329-335. [CrossRef]

97. Limbo, S.; Piergiovanni, L. Shelf life of minimally processed potatoes: Part 1. Effects of high oxygen partial pressures in combination with ascorbic and citric acids on enzymatic browning. Postharvest Biol. Technol. 2006, 39, 254-264. [CrossRef]

98. Aguayo, E.; Requejo-Jackman, C.; Stanley, R.; Woolf, A. Effects of calcium ascorbate treatments and storage atmosphere on antioxidant activity and quality of fresh-cut apple slices. Postharvest Biol. Technol. 2010, 57, 52-60. [CrossRef]

99. Xing, Y.; Li, X.; Xu, Q.; Jiang, Y.; Yun, J.; Li, W. Effects of chitosan-based coating and modified atmosphere packaging (MAP) on browning and shelf life of fresh-cut lotus root (Nelumbo nucifera Gaerth). Innov. Food Sci. Emerg. Technol. 2010, 11, 684-689. [CrossRef]

100. Arias, E.; López-Buesa, P.; Oria, R. Extension of fresh-cut “Blanquilla” pear (Pyrus communis L.) shelf-life by 1-MCP treatment after harvest. Postharvest Biol. Technol. 2009, 54, 53-58. [CrossRef]

101. Li, L.; Li, C.; Sun, J.; Xin, M.; Yi, P.; He, X.; Sheng, J.; Zhou, Z.; Ling, D.; Zheng, F.; et al. Synergistic effects of ultraviolet light irradiation and high-oxygen modified atmosphere packaging on physiological quality, microbial growth and lignification metabolism of fresh-cut carrots. Postharvest Biol. Technol. 2021, 173. [CrossRef]

102. Martín-Diana, A.B.; Rico, D.; Frías, J.M.; Barat, J.M.; Henehan, G.T.M.; Barry-Ryan, C. Calcium for extending the shelf life of fresh whole and minimally processed fruits and vegetables: A review. Trends Food Sci. Technol. 2007, 18, 210-218. [CrossRef]

103. Perez-Cabrera, L.; Chafer, M.; Chiralt, A.; Gonzalez-Martinez, C. Effectiveness of antibrowning agents applied by vacuum impregnation on minimally processed pear. LWT Food Sci. Technol. 2011, 44, 2273-2280. [CrossRef]

104. Abbott, J.A.; Saftner, R.A.; Gross, K.C.; Vinyard, B.T.; Janick, J. Consumer evaluation and quality measurement of fresh-cut slices of "Fuji," "Golden Delicious," "GoldRush," and "Granny Smith" apples. Postharvest Biol. Technol. 2004, 33, 127-140. [CrossRef]

105. Jiang, Y.; Pen, L.; Li, J. Use of citric acid for shelf life and quality maintenance of fresh-cut Chinese water chestnut. J. Food Eng. 2004, 63, 325-328. [CrossRef]

106. Amodio, M.L.; Cabezas-Serrano, A.B.; Peri, G.; Colelli, G. Post-cutting quality changes of fresh-cut artichokes treated with different anti-browning agents as evaluated by image analysis. Postharvest Biol. Technol. 2011, 62, 213-220. [CrossRef]

107. Gómez-López, V.M.; Ragaert, P.; Jeyachchandran, V.; Debevere, J.; Devlieghere, F. Shelf-life of minimally processed lettuce and cabbage treated with gaseous chlorine dioxide and cysteine. Int. J. Food Microbiol. 2008, 121, 74-83. [CrossRef] [PubMed]

108. Zhou, D.; Li, L.; Wu, Y.; Fan, J.; Ouyang, J. Salicylic acid inhibits enzymatic browning of fresh-cut Chinese chestnut (Castanea mollissima) by competitively inhibiting polyphenol oxidase. Food Chem. 2015, 171, 19-25. [CrossRef]

109. Altunkaya, A. Effect of whey protein concentrate on phenolic profile and browning of fresh-cut lettuce (Lactuca Sativa). Food Chem. 2011, 128, 754-760. [CrossRef]

110. Botondi, R.; Barone, M.; Grasso, C. A review into the effectiveness of ozone technology for improving the safety and preserving the quality of fresh-cut fruits and vegetables. Foods 2021, 10, 748. [CrossRef]

111. Rico, D.; Martín-Diana, A.B.; Frías, J.M.; Henehan, G.T.; Barry-Ryan, C. Effect of ozone and calcium lactate treatments on browning and texture properties of fresh-cut lettuce. J. Sci. Food Agric. 2006, 86, 2179-2188. [CrossRef]

112. Calder, B.L.; Skonberg, D.I.; Davis-Dentici, K.; Hughes, B.H.; Bolton, J.C. The Effectiveness of Ozone and Acidulant Treatments in Extending the Refrigerated Shelf Life of Fresh-Cut Potatoes. J. Food Sci. 2011, 76, 492-498. [CrossRef] [PubMed]

113. Sun, J.; Jiang, X.; Chen, Y.; Lin, M.; Tang, J.; Fang, L.; Li, M.; Hung, Y.; Lin, H. Recent trends and applications of electrolyzed oxidizing water. Food Chem. 2021, 130873. [CrossRef] 
114. Rico, D.; Martín-Diana, A.B.; Barry-Ryan, C.; Frías, J.M.; Henehan, G.T.M.; Barat, J.M. Use of neutral electrolysed water (EW) for quality maintenance and shelf-life extension of minimally processed lettuce. Innov. Food Sci. Emerg. Technol. 2008, 9, 37-48. [CrossRef]

115. Gómez-López, V.M.; Rajkovic, A.; Ragaert, P.; Smigic, N.; Devlieghere, F. Chlorine dioxide for minimally processed produce preservation: A review. Trends Food Sci. Technol. 2009, 20, 17-26. [CrossRef]

116. Cheng, D.; Wang, G.; Tang, J.; Yao, C.; Li, P.; Song, Q.; Wang, C. Inhibitory effect of chlorogenic acid on polyphenol oxidase and browning of fresh-cut potatoes. Postharvest Biol. Technol. 2020, 168, 111282. [CrossRef]

117. Rojas-Graü, M.A.; Soliva-Fortuny, R.; Martín-Belloso, O. Edible coatings to incorporate active ingredients to fresh-cut fruits: A review. Trends Food Sci. Technol. 2009, 20, 438-447. [CrossRef]

118. Yousuf, B.; Qadri, O.S.; Srivastava, A.K. Recent developments in shelf-life extension of fresh-cut fruits and vegetables by application of different edible coatings: A review. LWT Food Sci. Technol. 2018, 89, 198-209. [CrossRef]

119. Pen, L.T.; Jiang, Y.M. Effects of chitosan coating on shelf life and quality of fresh-cut Chinese water chestnut. LWT Food Sci. Technol. 2003, 36, 359-364. [CrossRef]

120. Qi, H.; Hu, W.; Jiang, A.; Tian, M.; Li, Y. Extending shelf-life of Fresh-cut "Fuji" apples with chitosan-coatings. Innov. Food Sci. Emerg. Technol. 2011, 12, 62-66. [CrossRef]

121. Montero-Calderón, M.; Rojas-Graü, M.A.; Martín-Belloso, O. Effect of packaging conditions on quality and shelf-life of fresh-cut pineapple (Ananas comosus). Postharvest Biol. Technol. 2008, 50, 182-189. [CrossRef]

122. Supapvanich, S.; Prathaan, P.; Tepsorn, R. Browning inhibition in fresh-cut rose apple fruit cv. Taaptimjaan using konjac glucomannan coating incorporated with pineapple fruit extract. Postharvest Biol. Technol. 2012, 73, 46-49. [CrossRef]

123. Bata Gouda, M.H.; Zhang, C.; Peng, S.; Kong, X.; Chen, Y.; Li, H.; Li, X.; Luo, H.; Yu, L. Combination of sodium alginate-based coating with L-cysteine and citric acid extends the shelf-life of fresh-cut lotus root slices by inhibiting browning and microbial growth. Postharvest Biol. Technol. 2021, 175, 111502. [CrossRef]

124. Lee, M.K. Inhibitory effect of banana polyphenol oxidase during ripening of banana by onion extract and Maillard reaction products. Food Chem. 2007, 102, 146-149. [CrossRef]

125. Yu, L.; Shi, H. Effect of two mulberry (Morus alba L.) leaf polyphenols on improving the quality of fresh-cut cantaloupe during storage. Food Control 2021, 121, 107624. [CrossRef]

126. Yousuf, B.; Wu, S.; Siddiqui, M.W. Incorporating essential oils or compounds derived thereof into edible coatings: Effect on quality and shelf life of fresh/fresh-cut produce. Trends Food Sci. Technol. 2021, 108, 245-257. [CrossRef]

127. Lu, Z.; Yu, Z.; Gao, X.; Lu, F.; Zhang, L. Preservation effects of gamma irradiation on fresh-cut celery. J. Food Eng. 2005, 67, 347-351. [CrossRef]

128. Zhang, L.; Lu, Z.; Lu, F.; Bie, X. Effect of $\gamma$ irradiation on quality-maintaining of fresh-cut lettuce. Food Control 2006, 17, 225-228. [CrossRef]

129. Zhan, L.; Li, Y.; Hu, J.; Pang, L.; Fan, H. Browning inhibition and quality preservation of fresh-cut romaine lettuce exposed to high intensity light. Innov. Food Sci. Emerg. Technol. 2012, 14, 70-76. [CrossRef]

130. Gómez, P.L.; Alzamora, S.M.; Castro, M.A.; Salvatori, D.M. Effect of ultraviolet-C light dose on quality of cut-apple: Microorganism, color and compression behavior. J. Food Eng. 2010, 98, 60-70. [CrossRef]

131. Zhang, Y.; Wang, Y.; Zhou, L.; Liao, X. A comparative study of inactivation of peach polyphenol oxidase and carrot polyphenol oxidase induced by high-pressure carbon dioxide. Int. J. Food Sci. Technol. 2010, 45, 2297-2305. [CrossRef]

132. Wu, Z.S.; Zhang, M.; Wang, S. Effects of high pressure argon treatments on the quality of fresh-cut apples at cold storage. Food Control 2012, 23, 120-127. [CrossRef] 